\title{
The Impact of Remittances on Poverty and Human Capital: Evidence from Latin American Household Surveys
}

\author{
Pablo Acosta, \\ (Corporación Andina de Fomento) \\ Pablo Fajnzylber and J. Humberto Lopez ${ }^{*}$ \\ (The World Bank)
}

\begin{abstract}
:
This paper explores the impact of remittances on poverty, education, and health in eleven Latin American countries using nationally representative household surveys and making an explicit attempt to account for one of the inherent costs associated with migration: the potential income that the migrant may have made at home. The main findings of the study are the following: (i) regardless of the counterfactual used remittances appear to lower poverty levels in most recipient countries; (ii) yet, despite this general tendency the estimated impacts tend to be modest; and (iii) there is significant country heterogeneity in the poverty reduction impact of remittances' flows. Among the aspects that have been identified in the paper that may lead to varying outcomes across countries are the percentage of households reporting remittances income, the share of remittances recipient households belonging to the lowest quintiles of the income distribution, and the relative importance of remittances flows with respect to GDP. While remittances tend to have positive effects on education and health, this impact is often restricted to specific groups of the population.
\end{abstract}

Keywords: remittances, poverty, human capital.

World Bank Policy Research Working Paper 4247, June 2007

The Policy Research Working Paper Series disseminates the findings of work in progress to encourage the exchange of ideas about development issues. An objective of the series is to get the findings out quickly, even if the presentations are less than fully polished. The papers carry the names of the authors and should be cited accordingly. The findings, interpretations, and conclusions expressed in this paper are entirely those of the authors. They do not necessarily represent the view of the World Bank, its Executive Directors, or the countries they represent. Policy Research Working Papers are available online at http:/lecon.worldbank.org.

\footnotetext{
* The views expressed in this paper should not be attributed to the Corporación Andina de Fomento, the World Bank, its Executive Directors or the countries they represent.
} 


\section{Introduction}

Workers' remittances to developing countries have experienced a dramatic increase over the past few years. According to the World Bank's Global Economic Prospects 2006, in 1990 remittances to middle and low-income countries amounted to about US\$30 billion. Fifteen years later, they are estimated to have reached almost US $\$ 170$ billion implying annual growth rates that are well above 10 percent. Remittances now account for about 30 percent of total financial flows to the developing world and provide significant foreign exchange earnings. They are more than twice as large as official development assistance flows, and represent the equivalent to 2.5 percent of the gross national income of the developing world. There is also some evidence indicating that remittances flows have a number of positive macroeconomic effects in recipient countries: large remittances flows improve a country's creditworthiness for external borrowing and hence enhance its access to international capital markets. Similarly, there is evidence that some financial institutions in developing countries have been able to tap international capital markets at relatively favorable conditions through securitization of future flows.

Given the nature, magnitude, and evolution of these flows it should not be a surprise that remittances are now seen by development practitioners as having a potentially important role to play in supporting the development efforts of recipient countries. There are two main channels in which remittances can support these efforts. First, remittances could flow towards the neediest groups of the population and therefore directly contribute to poverty reduction. Thus it is possible that even if these flows are fully consumed, a concern mentioned by a number of practitioners, they have significant positive welfare effects. Second, with imperfect insurance and financial markets, remittances can also contribute to higher investment in human and physical capital. For example, these flows can remove some of the financial constraints faced by households and small-scale entrepreneurs that prevented them from investing. Similarly, remittances can provide insurance and therefore allow households and entrepreneurs to pursue more risky asset accumulation strategies. Thus in this regard, remittances may also potentially contribute to raising the country's long run growth potential through higher rates of capital accumulation.

Unfortunately, in practice, these potential positive impacts may be counterbalanced by other more challenging effects. For example, if there are important costs associated to the act of migrating it is possible that migrants do not come from the lowest quintiles of the income distribution and therefore that remittances do not flow towards the poorest. In fact, as discussed below in the Latin American context, when one takes into account both the location of recipient households in the income distribution, and the magnitude of the corresponding flows it is difficult to defend that remittances are directed mainly towards the poor. In those cases, one should not expect remittances to have a large effect on poverty headcounts. Moreover, comparing observed poverty rates with those calculated on the basis of non-remittances income may exaggerate the estimated development impact of these flows. Indeed, before leaving their home countries migrants are likely to have contributed to their households' income, which should be taken into account when calculating counterfactual poverty rates in a scenario of neither migration nor remittances. Adams (2006), for example, argues that failure to correct for the reduction in income associated with the absence of 
migrants from their households can dramatically change the estimated poverty impact of remittances. With data from Guatemala, Adams (2004) illustrates how the incorporation or not of this correction can lead to either positive or negative effects of remittances on poverty.

Remittances can also negatively affect domestic competitiveness lowering the expected returns on capital. For example, remittances can exert pressure on the exchange rate and lead to a real appreciation something that ceteris paribus would lower the profitability of the tradable sector (in a Latin American context see Amuedo-Dorantes and Pozo, 2004, for evidence in this regard). Similarly, remittances may raise reservation wages and negatively affect labor supply (Rodriguez and Tiognson, 2001). In both cases, remittances would affect the investment incentives of households and entrepreneurs and lower the rate of capital accumulation.

In other words, given the potential counterbalancing effects associated to a surge in remittances, it may be quite difficult to determine not only the magnitude of the potential development impacts of remittances but also even the direction of those impacts. Thus, empirical evidence is needed to ascertain the signs and orders of magnitude of the different economic consequences of remittances flows. The existing empirical evidence on the various development impacts of remittances is, however, still quite limited. True, there are a number of studies ${ }^{1}$ which have analyzed the poverty impact of remittances ${ }^{2}$ exploiting cross national databases (see for example Adams and Page, 2005, and Acosta et al. 2007) or exploring the issue in specific country settings (see for example Adams 2004, 2006 respectively on Guatemala and Ghana, Lopez-Cordova, 2005; and Taylor, et al., 2005, on Mexico; and Yang and Martinez, 2005, on the Philippines) concluding that in general higher remittances inflows tend to be associated with lower poverty indicators.

Yet there are a number of issues that have to be considered. First, cross country studies tend to offer global results but they do not fully exploit differences in country characteristics that may affect the development impact of remittances. In particular, their results can be misleading in specific country contexts if there are significant differences in migration patterns across countries and regions, and those are not taken into account in the analysis. Moreover, cross country studies usually take as counterfactual the hypothesis of no remittances without altering migration patterns rather than the more appealing counterfactual of no migration (i.e. they underestimate the costs of migration and hence may overestimate the benefits of remittances). For example, some of the estimates obtained using cross country analyses suggest that that a 10 percent increase in per capita remittances may lead to a 3.5 percent decline in poverty. Clearly, this estimate does not seem very realistic especially when

\footnotetext{
${ }^{1}$ For comprehensive reviews see also the International Monetary Fund's World Economic Outlook 2005, the World Bank’s Global Economic Prospects 2006, and the Inter-American Development Bank's Beyond Small Changes: Making Migrants Remittances Count all of which have as its central topic the economic and development implications of remittances and migration.

2 The existing literature has also focused on the impact of remittances on other economic variables and measures of development. See for example the works of Yang (2006) for the impact of remittances on intertemporal consumption smoothing, Ruiz Arranz and Giuliano (2005) on growth; Amuedo-Dorantes and Pozo (2004) on risk management; Cox and Ureta (2003) and Hanson and Woodruff (2003) on education; Rodriguez and Tiognson (2001) on labor supply; Woodruff and Zenteno (2007) on entrepreneurship; and AmuedoDorantes and Pozo (2004) and Rajan and Subramaian (2005) on external competitiveness.
} 
one considers its implications: with this elasticity and the observed growth rates in per capita remittances observed during the past 15 years (above 10 percent), the existing poverty level in 1990 should have been almost halved by now just because of the remittances effect.

Country specific studies, on the other hand, allow for richer analyses but may offer a narrow view of the problem at hand if the existing stock of such studies is very limited. Moreover, the comparison of results may be problematic if the analyses of the various available studies rely on diverse methodologies and assumptions, so that it is difficult to disentangle whether the observed cross country differences are due to variation in country characteristics or to methodological differences across studies.

Against this background, this paper contributes to this debate by presenting an analysis of the development impact of remittances in eleven Latin American countries: Bolivia, Dominican Republic, Ecuador, El Salvador, Guatemala, Haiti, Honduras, Mexico, Nicaragua, Paraguay and Peru. These are the countries for which the respective nationally representative household surveys contain information of the remittances received by the different households. In this regard, the paper adds to the existing literature along several dimensions.

First, our results offer a comprehensive view of the poverty impact of workers remittances in the Latin American region. In our analysis we focus on the most commonly used poverty measure -headcount poverty- and explore how the results change when one uses different poverty lines and when one moves from internationally to nationally defined poverty lines. In this regard, our analysis extends and completes that in Acosta et al. (2007). While due to data limitations we do not analyze all the countries in the region that according to Balance of Payments' statistics receive non-trivial amounts of remittances flows, our working sample still covers more than two-thirds of the main remittances recipient countries in Latin America. This is even more important when one takes into account that Latin America is, together with East Asia and the Pacific, at the top of the ranking of remittances receiving regions in the world.

Second, unlike other studies on the topic which tend to focus either on the impact of remittances on poverty or on the impact of remittances on measures of household welfare that go beyond the pure income dimension such as education or health levels, our analysis looks at both issues. In the case of the impact of remittances on education we continue to work with eleven countries, although data limitations now prevent us from including Bolivia and instead allow us including Jamaica. In the case of health, our sample is much more limited and has only two countries: Guatemala and Nicaragua.

Third, for each of the development indicators on which we focus our analysis is based on a common methodology for all the countries so that differences in outcomes have to emerge from differences in the pattern and volume of remittances rather than from methodological biases. Thus, our results can be used to assess potential heterogeneity in the responses to a surge in remittances. To the best of our knowledge this is the first exercise of this type. In this respect, the paper brings together the virtues of cross country and country specific analysis. It has country specificity in the sense that each country is analyzed in 
isolation taking into account all the possible country characteristics. And it brings a cross country perspective because of the relatively large number of countries being analyzed using a common methodology, which permits an analysis of country heterogeneity.

Fourth, at a technical level, we present several exercises that are based on the same assumptions. In some cases we use as a counterfactual the scenario of migration without remittances; in others, we take as a counterfactual a situation without migration and hence correct for the potential income that migrants might have had if they had not left their country. To this end, we estimate an econometric model relating non remittances income to a set of household and household head characteristics. In addition, in what is our preferred simulation, we also take into account that households with migrants may not be randomly selected from the population and allow for possible selection bias. Moreover, following Schiff (2006), we also present the results of estimating the impact of remittances on the poverty rates prevailing only among the households receiving those flows. Finally, when estimating the effects of remittances on human capital formation, we control for the counterfactual income of recipient households estimated for the purpose of assessing the impact of remittances on poverty.

To anticipate some of the results below, we find that in general remittances tend to have an overall positive impact on recipient economies. Remittances seem to reduce poverty levels, increase educational attainment and contribute to improvements in health indicators. It is thus understandable that policy makers are increasingly interested in seeing an increase in the amount of remittances flowing to their countries.

Yet, in general the estimated impacts tend to be modest and show significant country heterogeneity. In this regard, our results indicate that in about half of the countries analyzed remittances do not have a significant impact on poverty. The main two reasons that explain this finding are the following. First, in some of the countries we analyze a large share of the remittances receiving population belongs to the top quintiles of the income distribution, which naturally reduces the potential poverty reducing effects of remittances flows. Second, correcting for the reduction in income that would be associated with the absence of migrants from their households has a significant impact. In fact, estimates that do not correct for this factor suggest significantly larger declines in poverty rates in all countries. We also find that children from households reporting remittances are more likely to stay at school and that controlling for pre-migration income children from remittances receiving households tend to exhibit higher health outcomes than those from non-recipients households with similar demographic and socio-economic characteristics (although in this case the evidence is based on only two countries). These impacts, however, tend to be restricted to households with relatively low levels of schooling and income.

The rest of the paper is structured as follows. In section II, we review the data and econometric methodology used in the paper. Section III presents the empirical results regarding the impact of remittances on headcount poverty. Section IV moves beyond the income dimension of poverty and explores how remittances affect human capital accumulation. Finally, section V offers concluding remarks. 


\section{Data and methodology}

\section{II.1 Data}

The dramatic increase in remittances observed at the global level over the past few years has been mirrored in Latin America. In fact, officially recorded remittances flows to the region have increased more than twenty-fold since 1980 when remittances amounted to about $\$ 1.9$ billion to close to US\$50 billion in 2005. These trends have placed Latin America (together with East Asia and the Pacific) at the top of the ranking of regions by total amount of remittances and more clearly by per capita remittances received. Moreover, according to World Bank 2006 on current trends remittances to the region could reach about US\$75 billion in 2007. While this estimate is likely to be on the high side of what one could expect, it nevertheless highlights the fact that a collapse in remittances does not seem very likely in the near future. In other words, it is not unrealistic to assume that remittances are here to stay, at least in the short run.

Within Latin America, remittances are particularly important in some countries. For example, they represent more than 50 percent of GDP in Haiti, a ratio that is the highest in the world, and between 15 and 20 percent of GDP in Jamaica, Honduras, and El Salvador (see figure 1.A). Similarly, in Guatemala, Nicaragua and the Dominican Republic remittances are between 10 and 12 percent of GDP. The importance of those flows can also be illustrated by comparison with other private capital flows. Thus, in Guatemala, Honduras, El Salvador and the Dominican Republic, remittances are equivalent to respectively 14, 4, 3 and 2 times FDI flows. Even in Colombia and Ecuador, where in relative terms remittances are lower, remittances represent respectively 197 and 112 percent of FDI.

On a US\$ basis, the Latin American country with the highest absolute remittances flows is Mexico, which received almost \$22 billion in 2005 (about \$18 billion in 2004, as reported in figure 1.B). This would represent 45 percent of total flows to Latin America in that year ( $\$ 48.3$ billion) and would make Mexico the largest world recipient in 2005. Other countries with substantial flows are Colombia and Brazil with flows of respectively \$3.8 and $\$ 3.5$ billion in 2005, and Guatemala, El Salvador, the Dominican Republic and Haiti with $\$ 2.5$ billion on average. Also worthy of note are Ecuador, Honduras, Jamaica and Peru, where remittances averaged about $\$ 1.5$ billion in 2005. Finally, on a per capita basis the country with the highest level of remittances would be Jamaica with approximately $\$ 550$ per capita, followed by Barbados with about $\$ 400$ per capita and El Salvador with flows of approximately $\$ 350$ (see figure 1.C). The average for the 28 countries being considered here would be $\$ 128$ per capita per year, but that amount increases to $\$ 270$ among the ten countries with highest per capita remittances - a group that also includes the Dominican Republic, Haiti, Antigua and Barbuda, Guatemala, Mexico, Honduras, and Trinidad and Tobago.

The data just described reveal the importance of remittances in the different Latin American countries. However, if interest centers on the characteristics of those receiving remittances the BOP data described above is not adequate and one has to resort to other sources. In this regard, the natural candidates are nationally representative household surveys. A problem with this alternative is that not all the Latin American countries have 
surveys containing relevant information on remittances. In fact, there are only 11 countries for which such data are available. Table 1 reports the countries for which the household survey allows an analysis of the poverty impact of remittances, together with some information regarding the year of the survey, and the survey used. Overall, remittances to these countries would have amounted in 2004 to US\$33.5 billion, or about 70 percent of total remittances to the region.

Figure 1. Remittances to Latin America in 2004

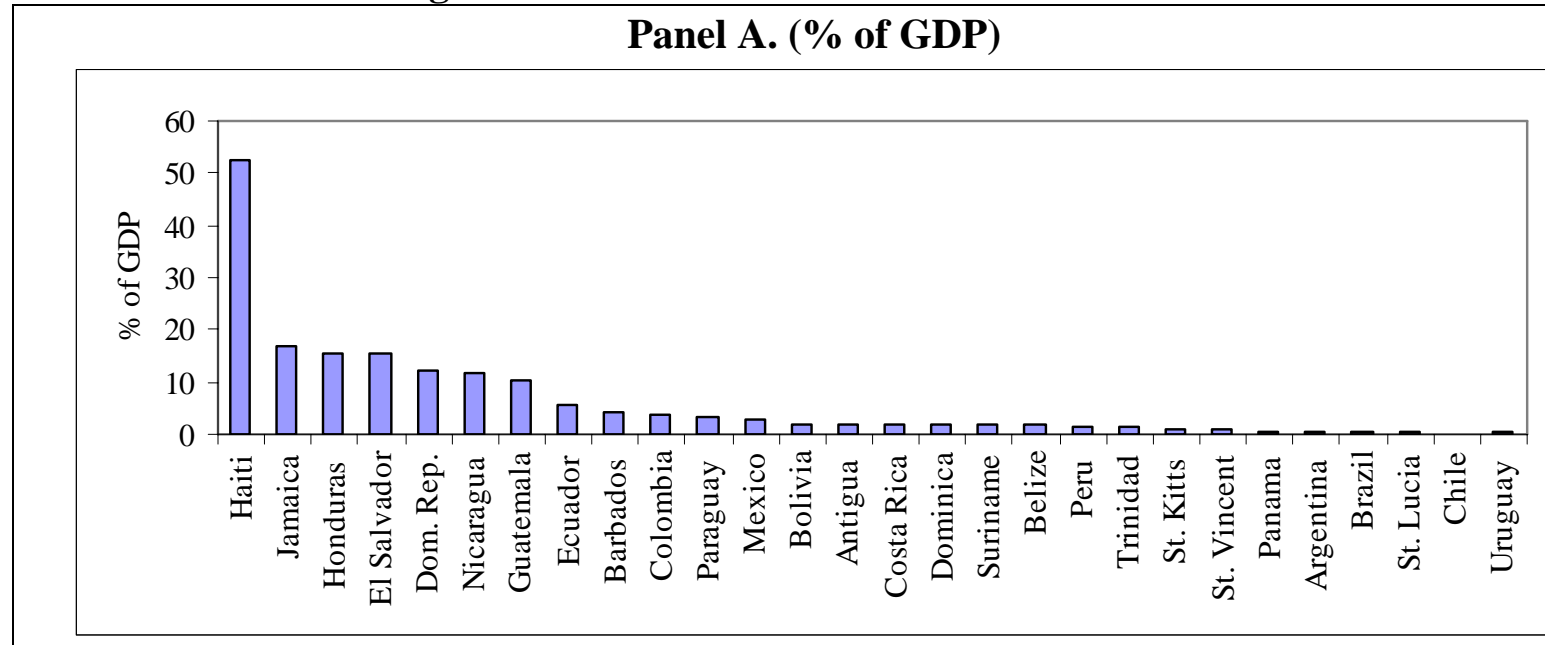

Panel B. (US\$ millions)

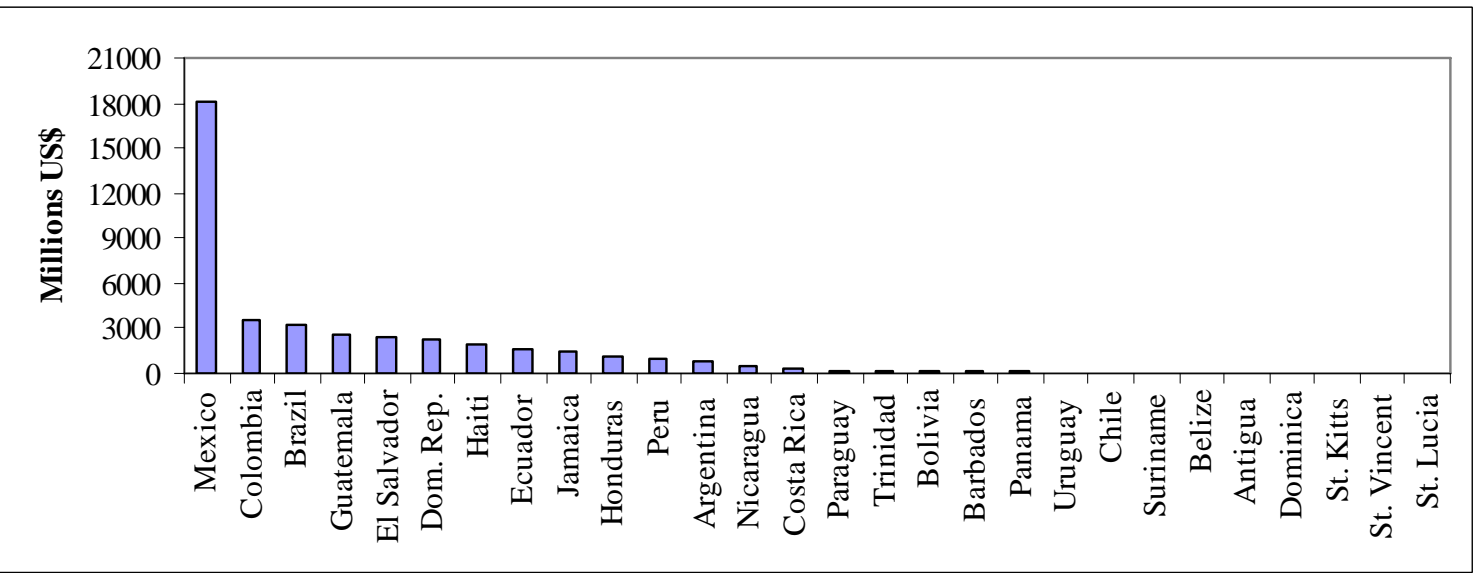




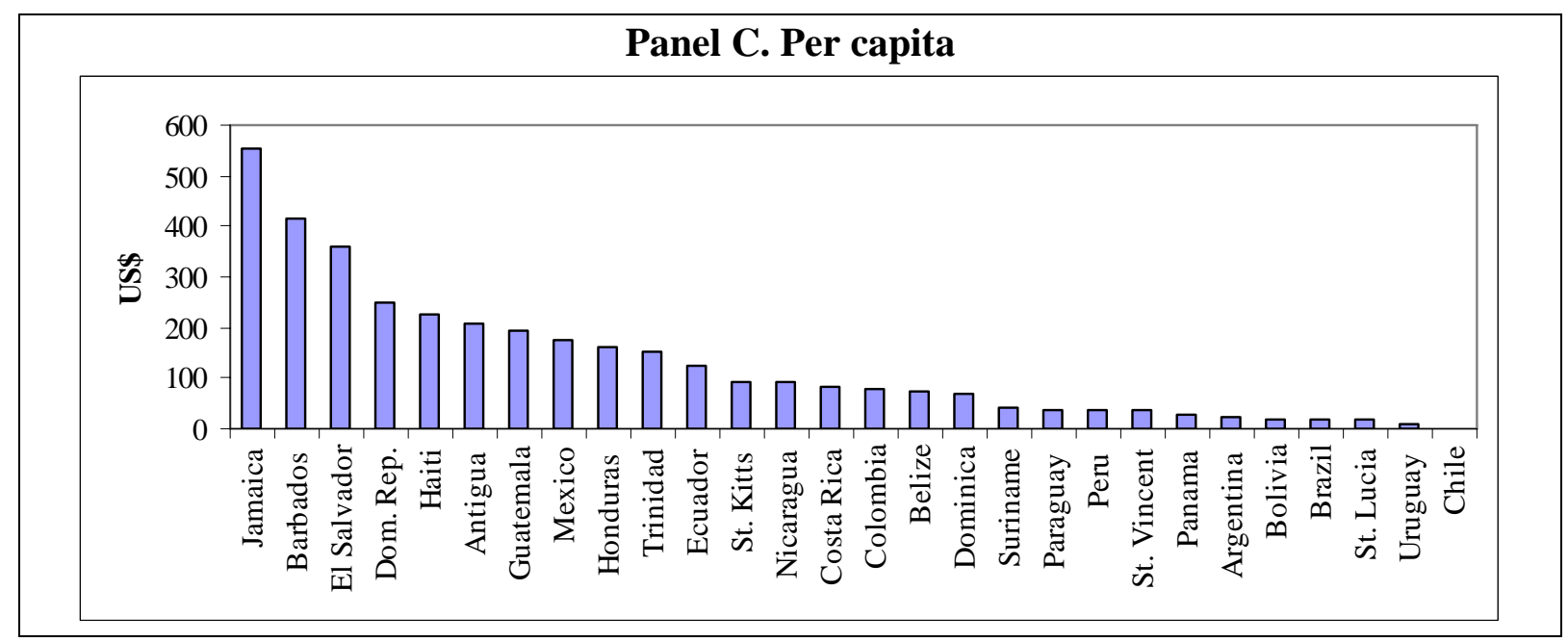

Source: Balance of Payments (macroeconomic) data.

Table 1. Household Surveys Used in the Paper

\begin{tabular}{lll}
\hline \multicolumn{1}{c}{ Country } & Year & \\
\hline Bolivia & 2002 & Encuesta de Hogares, MECOVI \\
Ecuador & 2004 & Sistema Integrado de Encuestas de Hogares, INEC \\
El Salvador & 2000 & Encuesta de Hogares de Propósitos Múltiples, MECOVI \\
Guatemala & 2000 & Encuesta Nacional sobre Condiciones de Vida (ENCOVI) \\
Haiti & 2001 & Les Conditions de Vie en Haiti, IHSI/Fafo/PNUD \\
Honduras & 2002 & Encuesta Permanente de Hogares de Propósitos Múltiples, MECOVI \\
Mexico & 2002 & Encuesta Nacional de Ingresos y Gastos de los Hogares, INEGI \\
Nicaragua & 2001 & Encuesta Nacional de Hogares sobre Medición de Nivel de Vida, INEC \\
Paraguay & 2003 & Encuesta Permanente de Hogares, Dirección General de Estadística \\
Peru & 2002 & Encuesta Nacional de Hogares, INEI \\
Rep. Dominicana & 2004 & Encuesta Nacional sobre Condiciones de Vida (ENCOVI) \\
\hline
\end{tabular}

One natural question that may arise at this stage regards the degree of consistency between the BOP based data and the survey based data. This is important in this context because significant and non-systematic discrepancies between the two data sources would raise a number of questions regarding the reliability of the remittances data and therefore of the results. In practice, however, we find that while there are significant differences between BOP and household survey estimates of remittances flows, those differences are at least systematic - i.e. the ordering of countries on the basis of remittances flows relative to GDP is very similar regardless of the data source. Indeed, Acosta et al. (2006) find that there is a stable relationship across countries between the two sources of data, with BOP based estimates surpassing household survey data estimates by about 73 percent (with an R2 of 0.8 obtained for the corresponding regression line linking the two series). That is, household survey based estimates of remittances flows (as a percent of household income) are about 40 percent lower than BOP based estimates (as a percent of GDP). While in principle these differences are likely to be motivated by reasons similar to those behind the existing 
discrepancies between household survey and national accounts based income estimates ${ }^{3}$ we cannot deny that it is also possible that household surveys are not fully representative of the population of remittances recipients and hence that they may underestimate the relevance of remittances flows. This is an important caveat that should be kept in mind when analyzing the results presented in this paper, because in that case we could be under-estimating the poverty reducing effects of remittances (although in a similar way across countries). With these elements in mind, the first question which we would like to respond on the basis of household survey data has to do with the characteristics of those receiving remittances in the sample of Latin American countries under consideration.

Figure 2. Share of households receiving remittances

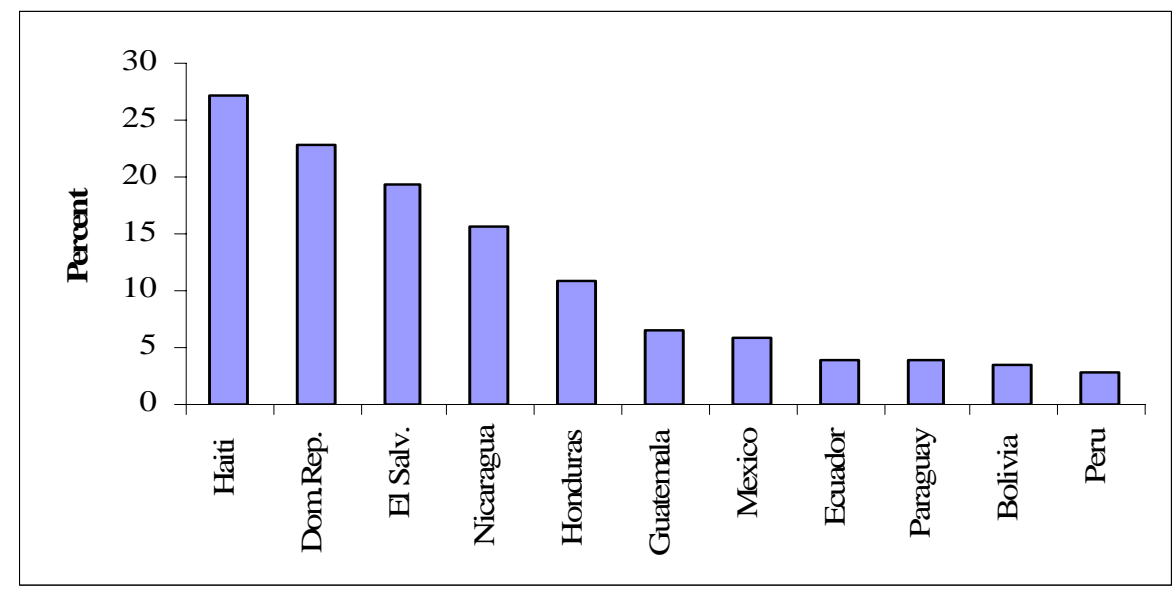

Source: Household surveys

To start with, figure 2 reports the share of households receiving remittances in each of the eleven countries in our sample, suggesting that this share varies significantly. For example, in Haiti more than 25 percent of the households reported having received remittances in 2001. At the other extreme, only 3 percent of the Peruvian households would benefit from these flows. In between, remittances reach between 10 and 25 percent of the households in the Dominican Republic, El Salvador, Nicaragua, and Honduras; between 5 and 10 percent in Mexico and Guatemala; and between 3 and 5 percent in Bolivia, Ecuador and Paraguay. Thus, other things being equal one should expect that a given amount of remittances could have quite different effects on the welfare of the population of countries such as for instance Peru and Haiti.

Cross country differences in the welfare effects of remittances become even more likely once one considers that not all the households receiving remittances are poor, and that the share of remittance recipients living in poverty varies considerably across countries. This is apparent from Figure 3 which plots the percentage of households receiving remittances by quintile of the (non-remittances) income distribution. The figure indicates that while in some countries the recipients of remittances are predominantly poor (61 percent of Mexican

\footnotetext{
${ }^{3}$ For example, Deaton (2005) estimates that on average survey income is less than 60 percent of GDP and discusses the reasons that may be behind survey and national accounts based estimates discrepancies.
} 
households receiving remittances fall in the first income quintile; 42 percent of Paraguayan recipients are in the first quintile of the distribution), this is not the case in all countries.

In Peru and Nicaragua, for example, the distribution of remittances recipients across households is completely different. In Peru less than 6 percent of the households that receive remittances belong to the lowest quintile while 40 percent belong to the top quintile. Similarly, in Nicaragua only 12 percent of the recipients are in the first quintile while 33 percent belong to the fifth quintile. Thus in these two countries remittances seem to be flowing towards the richest. Note that the interaction of these figures with the share of total households receiving remittances in the country would imply that less than .2 percent of the Peruvian population is made up of relatively poor households - i.e. first quintile of the income distribution- receiving remittances, and less than 2 percent of Nicaraguan households are remittances recipients and belong to the lowest quintile. Thus, in these two countries it is clear that even if we assume that the remittances received by each household are enough to take the household above the poverty line, the potential of remittances to lower poverty levels will be limited. Even in Mexico, where a majority of households receiving remittances belong to the lowest quintile, households receiving remittances and belonging to the lowest quintile would represent only 3 percent of the national population. Once again, this gives an idea of the orders of magnitude that we can find in the exercises below.

In between the groups of Mexico and Paraguay and the group of Peru and Nicaragua, there are three countries (Ecuador, El Salvador, and Guatemala) where recipients tend to be in lower quintiles (although in a less dramatic way than Mexico and Paraguay) and four countries (Bolivia, Honduras, the Dominican Republic and Haiti) where remittances appear to be homogeneously distributed across the distribution of income, or exhibit a U-shaped distribution (i.e. remittances flow to a larger extent towards the poorest and the richest quintiles). On the whole, the two countries where more than 5 percent of households pertain both to the group of remittances recipients and to the lowest quintile of the population are El Salvador and Haiti.

\section{2 Econometric Methodology}

The data described in the previous sub-section provides a firm footing to asses the impact of remittances on poverty. First, this data allows making mechanical comparisons of poverty rates calculated with remittances either excluded or included in total reported household income. These basic comparisons, however, suffer from one important shortcoming, namely that remittances are not likely to be an exogenous transfer but rather a substitute for the home earnings that migrants would have had if they had not decided to leave their countries to work abroad. In fact, the non-remittances income reported by households with migrants cannot be considered a good representation of the situation of the family prior to migration. If the migrant had positive earnings before leaving the household, it is likely that the household's total non-remittances income is lower after migration. Thus, estimating the effect of migration and remittances on poverty would require taking into consideration the counterfactual per capita income that the household would have had if the migrant had stayed at home, otherwise we would be overstating the true impact of migration and remittances on poverty reduction. 
Figure 3. Households receiving remittances by quintile of the non-remittances income distribution
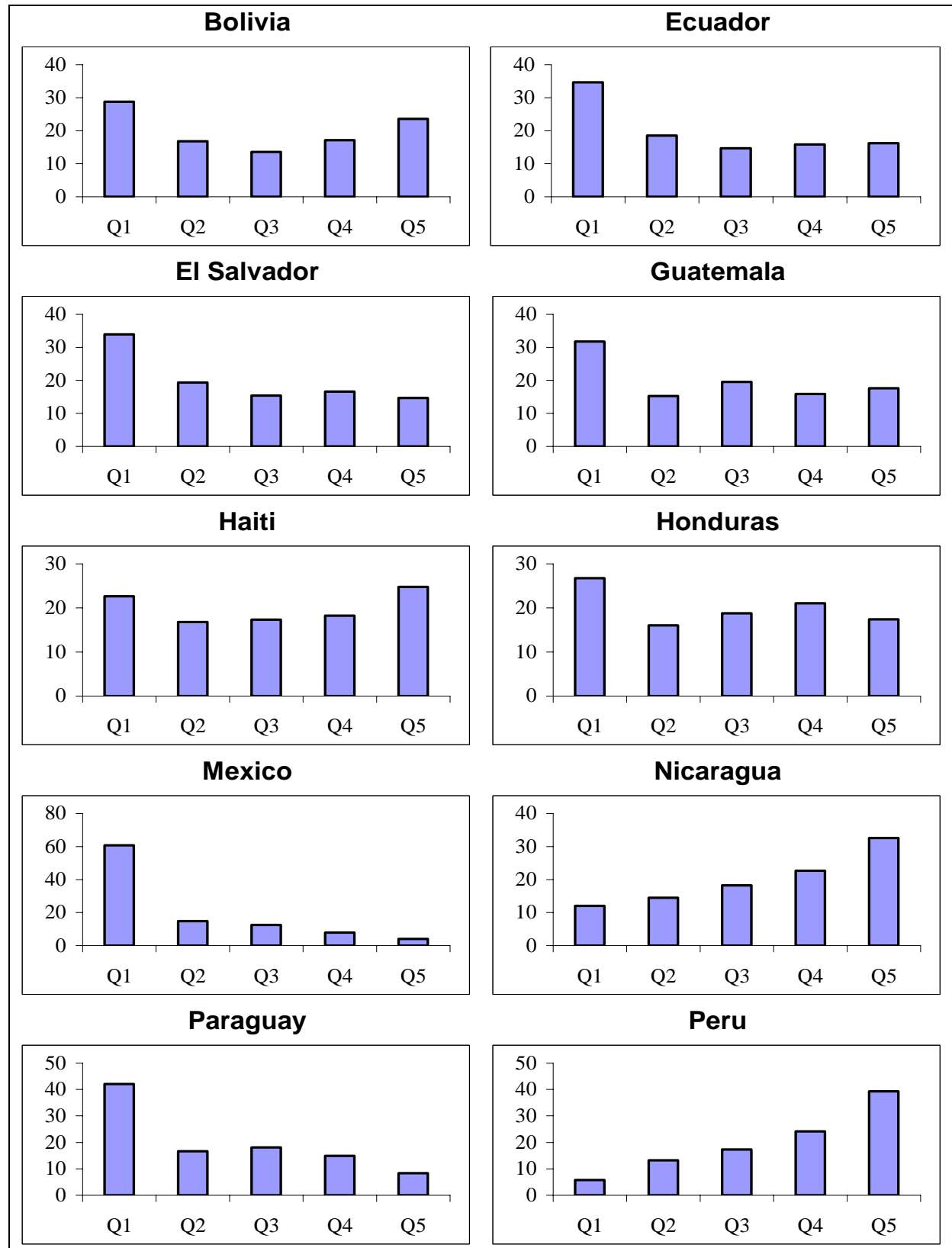

Dominican Republic

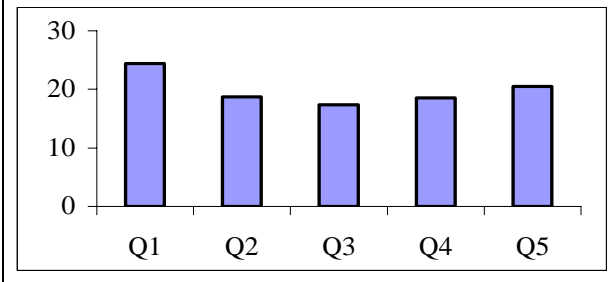

The figure reports the percentage of households receiving remittances that fall in each of the five quintiles of the income distribution.

Source: Own calculations using the last available household survey. 
One possible way to address this issue is as in Acosta et al. (2007) who impute per capita household income for migrant households in the counterfactual scenario of no remittances and no migration. Clearly, this requires information about the income of the household before the migrant left, and this information is in general not available directly from household surveys. As an alternative, Acosta et al. (2007) infer the counterfactual per capita income levels for those households with remittances on the basis of a reduced-form specification for the determinants of income among households without remittances. More formally, this approach involves estimating a model like:

$$
\log Y_{i}=\alpha+\beta X_{i}+\gamma H_{i}+\mu_{i}
$$

where $Y_{i}$ represents per capita non-remittances income, $X_{i}$ is a vector of household characteristics (demographic and location covariates), $H_{i}$ is a set of characteristics of the household head, and $\mu_{i}$ represents random shocks and possible unobserved heterogeneity in income generation. Equation (1) can be estimated using the sub-sample of households that do not receive remittances. The estimated coefficients then allow predicting the counterfactual non-migration income for remittances-recipient households. In the absence of information on migrant characteristics - which is the case of all the countries considered in this paper except Haiti and Nicaragua - it is necessary to make some basic assumptions about the number and the demographics of migrants. Following Rodriguez (1998) and Acosta et al. (2007), we assume that, on average, remittances are sent by a single adult male family member. Another needed assumption has to do with the education level of the migrant, which we assume to be equal to the average years of education of other adults in the household.

One additional aspect that needs attention is that OLS estimates of equation (1) will be inconsistent if $\mu_{i}$ is not independently identically distributed (i.i.d.). In other words, if migrants are not randomly selected from the pool of households, estimates of equation (1) based on the sample of households without migrants could suffer from selection bias. To control for this possibility, we add to (1) a variable that represents the household's "propensity to not migrate or not receive remittances" $\left(M_{i}{ }^{*}\right)$. This new term is calculated in the context of the two-step estimation framework proposed by Heckman (1979). In particular, we adopt the following model specification:

$M_{i}^{*}=\alpha_{1}+\beta_{1} X_{i}+\gamma_{1} H_{i}+\omega Z_{i}+v_{i}$

(no-remittances selection rule)

$\log Y_{i}=\alpha_{2}+\beta_{2} X_{i}+\gamma_{2} H_{i}+\theta \lambda_{i}+\varepsilon_{i}$

(earnings equation for non-recipient households)

In practice, one can only observe the sign of the variable $M_{i}{ }^{*}$, which represents the selection rule for no migration or not receiving remittances i.e. whether the household receives remittances or not, which in turns is equivalent to a negative or positive value for $M_{i}{ }^{*}$. Identification of this model requires an exclusion restriction: a set of variables $Z_{i}$ that are 
related to the migration and remittances choice but which do not directly affect earnings for households with non-migrants. The term $\lambda_{i}$ is the selection inverse Mill's ratio, defined as:

$$
\lambda_{i}=\frac{\phi\left(\alpha_{1}+\beta_{1} X_{i}+\gamma_{1} H_{i}+\omega Z_{i}\right)}{1-\Phi\left(\alpha_{1}+\beta_{1} X_{i}+\gamma_{1} H_{i}+\omega Z_{i}\right)}
$$

with

$$
\theta \lambda_{i}=E\left(v_{i} / \mu_{i}>-\beta_{1} X_{i}-\gamma_{1} H_{i}-\omega Z_{i}\right)
$$

where $\mu_{i}$ is the error component in the earning equations and $\theta=\operatorname{cov}\left(v_{i}, \mu_{i}\right) / \sqrt{\operatorname{var}\left(\mu_{i}\right)}$. Controlling for $\lambda_{i}$ allows the remaining unexplained component $\varepsilon_{i}$ to have the usual desirable i.i.d. properties. If $\lambda_{i}$ is a significant predictor of earnings, it suggests that the selection into the non-migration status is indeed correlated with factors that affect household earnings - and that OLS estimates of equation (1) would be inconsistent.

The exclusion restrictions that we employ for the non-remittances selection equation are an index of household assets, the percentage of households that receive remittances in the respective county of residence (a proxy for the presence of migrant networks), and their interaction. When county level indicators cannot be calculated (Guatemala and Haiti), the variable that represents the percentage of households with migrants is measured at the department/province level. In this case, only the interaction of that variable with the household assets index is included. Finally, when information on household assets is missing (Bolivia, Ecuador and Honduras), the network variable is interacted with the number of adult males, which ensures variability at the household level. ${ }^{4}$

With the assumption stated before concerning migrant characteristics, these coefficients are used in order to impute the counterfactual non-remittances per capita household income for recipient households. With this variable one can proceed to calculate the levels of poverty and inequality that would have prevailed had migration and remittances not taken place. It must be noted, however, that as mentioned by Rodriguez (1998) the

\footnotetext{
${ }^{4}$ The percentage of households receiving remittances in the same county (or province) is a proxy for migration networks at the county (province) levels. Previous literature has used migration networks as instruments for migration and remittances in order to assess their impact on development outcomes (Hanson and Woodruff, 2003; Lopez-Cordova, 2005; Acosta, 2006; Acosta et al., 2006; Woodruff and Zenteno, 2007). In the countries under analysis, the correlation between the fraction of recipient households in each county or province and the per capita income of non-recipient households in the same area is non-significantly different from zero in 9 out of 11 cases (where it varies from -0.038 to 0.043 ) and it is still very low in the other 2 cases (0.14 in Haiti and 0.16 in Peru).
} 
variance of the counterfactual income predicted on the basis of observable household characteristics is artificially small, because it ignores unobserved determinants of income.

A potential solution proposed by Barham and Boucher (1998) is to add to the predicted household income a random error component drawn from a distribution with the same properties (mean, variance) of the actual estimated errors. We pursue this approach and obtain 1,000 different estimates of the imputed counterfactual non-remittances income for households with migrants, and the same number of estimates for the poverty and inequality levels that would have prevailed in the above counterfactual scenario. This allows us to report not only point estimates for those variables but also 95\% confident intervals, based on the 25th and 975th estimates of the variables - after sorting them in ascending order.

\section{Results}

We start this section by reviewing the estimates corresponding to the two-step model described in equations (2) and (3) which are reported in Tables 2 and 3. Unlike in Barham and Boucher (1998) and Adams (2006), we find that $\lambda_{i}$ is positive and significant at the 1 percent level in all cases except Ecuador, an indication that recipients of remittances are not randomly selected from the complete pool of households. Moreover, this result suggests that households with a lower propensity to migrate are also more likely to have higher per capita income levels, which is consistent with the standard migration argument that potential migrants compare the returns at home and in their potential destination when deciding whether to work abroad.

The rest of the coefficients have the expected signs. In the selection equation, larger households (particularly those with a higher number of adult males) are more likely to receive remittances (or migrate). On the other hand, the number of children and adult females is negatively related to the likelihood of migration and remittances receipts. Higher educational levels are negatively related to remittances, except in Haiti and Honduras (where education has the opposite sign). The presence of migrant networks, proxied by the percentage of households with remittances in the area of residence, and a household wealth index also seem positively and significantly correlated with the likelihood of being a recipient. In the earnings equation, as expected, education and demographic characteristics are strong significant predictors of income in non-recipient households, explaining between 33 and 55 percent of income variability depending on the case. 
Table 2. Two-Step Estimates of Non-Remittances Household Income

Auxiliary Regressions - Per Capita Income for HHs Not Recipient of Remittances. Heckman's Two Step Results

Dependent Variable: Log of Per Capita HH Income

\begin{tabular}{|c|c|c|c|c|c|c|c|c|c|c|c|}
\hline Variables & Mexico & Guatemala & El Salvador & Paraguay & Honduras & Dom. Rep. & Bolivia & Ecuador & Haiti & Peru & Nicaragua \\
\hline HH Size & $\begin{array}{c}-0.102^{* * *} \\
(0.015)\end{array}$ & $\begin{array}{c}-0.113^{* * *} \\
(0.039)\end{array}$ & $\begin{array}{c}-0.214^{* * *} \\
(0.021)\end{array}$ & $\begin{array}{c}-0.087 * * * \\
(0.026)\end{array}$ & $\begin{array}{c}-0.125 * * * \\
(0.020)\end{array}$ & $\begin{array}{c}-0.166 * * * \\
(0.035)\end{array}$ & $\begin{array}{c}-0.088^{* *} \\
(0.042)\end{array}$ & $\begin{array}{c}-0.134 * * * \\
(0.017)\end{array}$ & $\begin{array}{c}-0.296 * * * \\
(0.043)\end{array}$ & $\begin{array}{c}-0.141 * * * \\
(0.013)\end{array}$ & $\begin{array}{c}-0.205^{* * *} \\
(0.045)\end{array}$ \\
\hline Number $0-5$ years old children & $\begin{array}{c}-0.146 * * * \\
(0.017)\end{array}$ & $\begin{array}{r}-0.055 \\
(0.042)\end{array}$ & $\begin{array}{l}0.024 \\
(0.023)\end{array}$ & $\begin{array}{c}-0.175 * * * \\
(0.029)\end{array}$ & $\begin{array}{c}-0.089 * * * \\
(0.021)\end{array}$ & $\begin{array}{c}-0.070^{*} \\
(0.038)\end{array}$ & $\begin{array}{c}-0.129 * * \\
(0.046)\end{array}$ & $\begin{array}{c}-0.102 * * * \\
(0.019)\end{array}$ & $\begin{array}{l}0.032 \\
(0.048)\end{array}$ & $\begin{array}{c}-0.076 * * * \\
(0.015)\end{array}$ & $\begin{array}{l}0.007 \\
(0.049)\end{array}$ \\
\hline Number of 6-15 years old boys & $\begin{array}{c}-0.100 * * * \\
(0.017)\end{array}$ & $\begin{array}{l}-0.031 \\
(0.042)\end{array}$ & $\begin{array}{l}0.033 \\
(0.023)\end{array}$ & $\begin{array}{c}-0.121 * * * \\
(0.028)\end{array}$ & $\begin{array}{c}-0.045^{* *} \\
(0.021)\end{array}$ & $\begin{array}{l}-0.043 \\
(0.038)\end{array}$ & $\begin{array}{c}-0.121^{* *} \\
(0.046)\end{array}$ & $\begin{array}{c}-0.068 * * * \\
(0.019)\end{array}$ & $\begin{array}{c}0.161 * * * \\
(0.047)\end{array}$ & $\begin{array}{c}-0.049 * * * \\
(0.014)\end{array}$ & $\begin{array}{l}0.062 \\
(0.048)\end{array}$ \\
\hline Number of 6-15 years old girls & $\begin{array}{c}-0.103^{* * *} \\
(0.017)\end{array}$ & $\begin{array}{l}-0.043 \\
(0.042)\end{array}$ & $\begin{array}{l}0.038 \\
(0.023)\end{array}$ & $\begin{array}{c}-0.097 * * * \\
(0.028)\end{array}$ & $\begin{array}{c}-0.053^{* *} \\
(0.021)\end{array}$ & $\begin{array}{l}-0.050 \\
(0.038)\end{array}$ & $\begin{array}{c}-0.093^{* *} \\
(0.046)\end{array}$ & $\begin{array}{c}-0.066 * * * \\
(0.019)\end{array}$ & $\begin{array}{c}0.128^{* * *} \\
(0.047)\end{array}$ & $\begin{array}{c}-0.046 * * * \\
(0.014)\end{array}$ & $\begin{array}{l}0.028 \\
(0.048)\end{array}$ \\
\hline Number of $16-65$ years old males & $\begin{array}{c}0.041^{* * *} \\
(0.016)\end{array}$ & $\begin{array}{l}0.006 \\
(0.043)\end{array}$ & $\begin{array}{c}0.048^{* *} \\
(0.022)\end{array}$ & $\begin{array}{c}0.061 * * \\
(0.026)\end{array}$ & $\begin{array}{c}0.135 * * * \\
(0.020)\end{array}$ & $\begin{array}{c}0.103 * * * \\
(0.037)\end{array}$ & $\begin{array}{l}-0.034 \\
(0.043)\end{array}$ & $\begin{array}{c}0.183^{* * *} \\
(0.018)\end{array}$ & $\begin{array}{c}-0.161 * * * \\
(0.047)\end{array}$ & $\begin{array}{c}0.073 * * * \\
(0.013)\end{array}$ & $\begin{array}{c}0.147 * * * \\
(0.048)\end{array}$ \\
\hline Number of $16-65$ years old females & $\begin{array}{c}0.040 * * \\
(0.016)\end{array}$ & $\begin{array}{c}0.154 * * * \\
(0.041)\end{array}$ & $\begin{array}{c}0.228 * * * \\
(0.022)\end{array}$ & $\begin{array}{l}0.039 \\
(0.027)\end{array}$ & $\begin{array}{c}0.087 * * * \\
(0.020)\end{array}$ & $\begin{array}{l}-0.010 \\
(0.036)\end{array}$ & $\begin{array}{l}0.009 \\
(0.043)\end{array}$ & $\begin{array}{c}0.065^{* * *} \\
(0.018)\end{array}$ & $\begin{array}{c}0.192 * * * \\
(0.045)\end{array}$ & $\begin{array}{c}0.082 * * * \\
(0.013)\end{array}$ & $\begin{array}{c}0.181 * * * \\
(0.047)\end{array}$ \\
\hline Rural Area & & $\begin{array}{c}-0.377 * * * \\
(0.031)\end{array}$ & $\begin{array}{c}-0.419^{* * * *} \\
(0.018)\end{array}$ & $\begin{array}{c}-0.203 * * * \\
(0.020)\end{array}$ & $\begin{array}{c}-0.395 * * * \\
(0.015)\end{array}$ & $\begin{array}{l}-0.022 \\
(0.023)\end{array}$ & $\begin{array}{c}-0.687 * * * \\
(0.030)\end{array}$ & $\begin{array}{c}-0.332 * * * \\
(0.015)\end{array}$ & $\begin{array}{c}0.134 * * * \\
(0.049)\end{array}$ & & $\begin{array}{c}-0.292 * * * \\
(0.037)\end{array}$ \\
\hline Avg. Adult Education (16-65 years old) & $\begin{array}{c}0.074 * * * \\
(0.002)\end{array}$ & $\begin{array}{c}0.102 * * * \\
(0.006)\end{array}$ & $\begin{array}{c}0.071 * * * \\
(0.003)\end{array}$ & $\begin{array}{c}0.055^{* * * *} \\
(0.004)\end{array}$ & $\begin{array}{c}0.073 * * * \\
(0.003)\end{array}$ & $\begin{array}{c}0.072 * * * \\
(0.005)\end{array}$ & $\begin{array}{c}0.056^{* * *} \\
(0.005)\end{array}$ & $\begin{array}{c}0.045^{* * *} \\
(0.003)\end{array}$ & $\begin{array}{c}0.046 * * * \\
(0.009)\end{array}$ & $\begin{array}{c}0.068 * * * \\
(0.002)\end{array}$ & $\begin{array}{c}0.066 * * * \\
(0.007)\end{array}$ \\
\hline Age (HH Head) & $\begin{array}{c}0.032 * * * \\
(0.002)\end{array}$ & $\begin{array}{c}0.043 * * * \\
(0.006)\end{array}$ & $\begin{array}{c}0.023 * * * \\
(0.003)\end{array}$ & $\begin{array}{l}0.000 \\
(0.004)\end{array}$ & $\begin{array}{c}0.011 * * * \\
(0.003)\end{array}$ & $\begin{array}{c}0.042 * * * \\
(0.004)\end{array}$ & $\begin{array}{c}0.018 * * * \\
(0.005)\end{array}$ & $\begin{array}{c}0.011 * * * \\
(0.003)\end{array}$ & $\begin{array}{c}0.019^{* * *} \\
(0.006)\end{array}$ & $\begin{array}{c}0.011 * * * \\
(0.002)\end{array}$ & $\begin{array}{c}0.017 * * * \\
(0.006)\end{array}$ \\
\hline Age Squared x 100 (HH Head) & $\begin{array}{c}-0.026 * * * \\
(0.002)\end{array}$ & $\begin{array}{c}-0.045^{* * * *} \\
(0.007)\end{array}$ & $\begin{array}{c}-0.024^{* * * *} \\
(0.003)\end{array}$ & $\begin{array}{l}0.005 \\
(0.004)\end{array}$ & $\begin{array}{c}-0.009^{* * *} \\
(0.003)\end{array}$ & $\begin{array}{c}-0.044 * * * \\
(0.005)\end{array}$ & $\begin{array}{l}-0.008 \\
(0.006)\end{array}$ & $\begin{array}{c}-0.007 * * * \\
(0.003)\end{array}$ & $\begin{array}{c}-0.024 * * * \\
(0.006)\end{array}$ & $\begin{array}{l}-0.003 \\
(0.002)\end{array}$ & $\begin{array}{c}-0.015^{* *} \\
(0.006)\end{array}$ \\
\hline Years of Education (HH Head) & $\begin{array}{c}0.042^{* * * *} \\
(0.002)\end{array}$ & $\begin{array}{c}0.038^{* * * *} \\
(0.005)\end{array}$ & $\begin{array}{c}0.030^{* * * *} \\
(0.003)\end{array}$ & $\begin{array}{c}0.051 * * * \\
(0.003)\end{array}$ & $\begin{array}{c}0.036 * * * \\
(0.003)\end{array}$ & $\begin{array}{c}0.014 * * * \\
(0.004)\end{array}$ & $\begin{array}{c}0.047 * * * \\
(0.005)\end{array}$ & $\begin{array}{c}0.045^{* * *} \\
(0.002)\end{array}$ & $\begin{array}{c}0.029 * * * \\
(0.007)\end{array}$ & $\begin{array}{c}0.027 * * * \\
(0.002)\end{array}$ & $\begin{array}{c}0.020^{* * *} \\
(0.006)\end{array}$ \\
\hline Lambda & $\begin{array}{c}0.379 * * * \\
(0.045)\end{array}$ & $\begin{array}{c}2.245 * * * \\
(0.184)\end{array}$ & $\begin{array}{c}0.915 * * * \\
(0.049)\end{array}$ & $\begin{array}{c}0.457 * * * \\
(0.132)\end{array}$ & $\begin{array}{c}0.300 * * * \\
(0.060)\end{array}$ & $\begin{array}{c}0.600 * * * \\
(0.068)\end{array}$ & $\begin{array}{c}0.382 * * \\
(0.152)\end{array}$ & $\begin{array}{l}0.128 \\
(0.090)\end{array}$ & $\begin{array}{c}1.575 * * * \\
(0.140)\end{array}$ & $\begin{array}{c}1.333 * * * \\
(0.076)\end{array}$ & $\begin{array}{c}0.718 * * * \\
(0.114)\end{array}$ \\
\hline Department/Province Indicators & Yes & Yes & Yes & Yes & Yes & Yes & Yes & Yes & Yes & Yes & Yes \\
\hline Observations & 15130 & 6529 & 12201 & 9031 & 19052 & 7507 & 5289 & 17446 & 5267 & 17897 & 3445 \\
\hline R-Squared & 0.5499 & 0.4327 & 0.4540 & 0.4160 & 0.5095 & 0.3265 & 0.4430 & 0.3930 & 0.3286 & 0.5350 & 0.4040 \\
\hline
\end{tabular}

*Significant at $10 \%$ level. **Significant at 5\%level. ***Significant at $1 \%$ level. 
Table 3. Two-Step Estimates of Non-Remittances Household Income

Auxiliary Regressions - First Step Results

Dependent Variable: HHs Not Recipient of Remittances Indicator

\begin{tabular}{|c|c|c|c|c|c|c|c|c|c|c|c|}
\hline Variables & Mexico & Guatemala & El Salvador & Paraguay & Honduras & Dom. Rep. & Bolivia & Ecuador & Haiti & Peru & Nicaragua \\
\hline HH Size & $\begin{array}{c}-0.145^{* * *} \\
(0.053)\end{array}$ & $\begin{array}{l}-0.002 \\
(0.072)\end{array}$ & $\begin{array}{c}-0.280^{* * *} \\
(0.031)\end{array}$ & $\begin{array}{c}-0.254^{* * *} \\
(0.062)\end{array}$ & $\begin{array}{c}-0.248^{* * *} \\
(0.035)\end{array}$ & $\begin{array}{c}-0.194 * * * \\
(0.051)\end{array}$ & $\begin{array}{c}-0.423^{* * *} \\
(0.095)\end{array}$ & $\begin{array}{l}-0.065 \\
(0.049)\end{array}$ & $\begin{array}{c}-0.235 * * * \\
(0.047)\end{array}$ & $\begin{array}{l}-0.106 \\
(0.066)\end{array}$ & $\begin{array}{l}-0.095 \\
(0.076)\end{array}$ \\
\hline Number $0-5$ years old children & $\begin{array}{l}0.105^{*} \\
(0.060)\end{array}$ & $\begin{array}{l}0.093 \\
(0.079)\end{array}$ & $\begin{array}{c}0.288^{* * *} \\
(0.035)\end{array}$ & $\begin{array}{c}0.257 * * * \\
(0.072)\end{array}$ & $\begin{array}{c}0.277 * * * \\
(0.038)\end{array}$ & $\begin{array}{c}0.226 * * * \\
(0.057)\end{array}$ & $\begin{array}{c}0.552^{* * *} \\
(0.112)\end{array}$ & $\begin{array}{l}0.096 * \\
(0.056)\end{array}$ & $\begin{array}{c}0.281^{* * *} \\
(0.053)\end{array}$ & $\begin{array}{c}0.172^{* * *} \\
(0.081)\end{array}$ & $\begin{array}{l}0.137 \\
(0.085)\end{array}$ \\
\hline Number of 6-15 years old boys & $\begin{array}{c}0.150 * * \\
(0.060)\end{array}$ & $\begin{array}{l}-0.027 \\
(0.078)\end{array}$ & $\begin{array}{c}0.258 * * * \\
(0.036)\end{array}$ & $\begin{array}{c}0.228 * * * \\
(0.071)\end{array}$ & $\begin{array}{c}0.216 * * * \\
(0.038)\end{array}$ & $\begin{array}{c}0.181 * * * \\
(0.057)\end{array}$ & $\begin{array}{c}0.484 * * * \\
(0.108)\end{array}$ & $\begin{array}{l}0.019 \\
(0.055)\end{array}$ & $\begin{array}{c}0.247 * * * \\
(0.052)\end{array}$ & $\begin{array}{l}0.057 \\
(0.078)\end{array}$ & $\begin{array}{l}0.089 \\
(0.082)\end{array}$ \\
\hline Number of 6-15 years old girls & $\begin{array}{c}0.159 * * * \\
(0.060)\end{array}$ & $\begin{array}{r}-0.052 \\
(0.079)\end{array}$ & $\begin{array}{c}0.235 * * * \\
(0.035)\end{array}$ & $\begin{array}{c}0.236 * * * \\
(0.070)\end{array}$ & $\begin{array}{c}0.184 * * * \\
(0.038)\end{array}$ & $\begin{array}{c}0.190 * * * \\
(0.057)\end{array}$ & $\begin{array}{c}0.434 * * * \\
(0.107)\end{array}$ & $\begin{array}{l}-0.020 \\
(0.055)\end{array}$ & $\begin{array}{c}0.235 * * * \\
(0.052)\end{array}$ & $\begin{array}{l}0.066 \\
(0.077)\end{array}$ & $\begin{array}{l}0.109 \\
(0.083)\end{array}$ \\
\hline Number of $16-65$ years old males & $\begin{array}{c}-0.379 * * * \\
(0.055)\end{array}$ & $\begin{array}{c}-0.412 * * * \\
(0.074)\end{array}$ & $\begin{array}{c}-0.306^{* * * *} \\
(0.033)\end{array}$ & $\begin{array}{c}-0.123^{*} \\
(0.064)\end{array}$ & $\begin{array}{c}-0.080^{*} \\
(0.042)\end{array}$ & $\begin{array}{c}-0.509 * * * \\
(0.053)\end{array}$ & $\begin{array}{c}-0.059 \\
(0.105)\end{array}$ & $\begin{array}{c}-0.194 * * * \\
(0.054)\end{array}$ & $\begin{array}{c}-0.330 * * * \\
(0.048)\end{array}$ & $\begin{array}{c}-0.265 * * * \\
(0.068)\end{array}$ & $\begin{array}{c}-0.369 * * * \\
(0.080)\end{array}$ \\
\hline Number of $16-65$ years old females & $\begin{array}{c}0.190 * * * \\
(0.056)\end{array}$ & $\begin{array}{l}0.045 \\
(0.076)\end{array}$ & $\begin{array}{c}0.299 * * * \\
(0.033)\end{array}$ & $\begin{array}{c}0.302 * * * \\
(0.067)\end{array}$ & $\begin{array}{c}0.196 * * * \\
(0.037)\end{array}$ & $\begin{array}{c}0.188^{* * *} \\
(0.054)\end{array}$ & $\begin{array}{c}0.361 * * * \\
(0.098)\end{array}$ & $\begin{array}{c}0.166 * * * \\
(0.052)\end{array}$ & $\begin{array}{c}0.237 * * * \\
(0.049)\end{array}$ & $\begin{array}{c}0.188^{* * *} \\
(0.068)\end{array}$ & $\begin{array}{c}0.176^{* *} \\
(0.078)\end{array}$ \\
\hline Rural Area & & $\begin{array}{c}-0.114 * \\
(0.066)\end{array}$ & $\begin{array}{c}-0.164^{* * * *} \\
(0.034)\end{array}$ & $\begin{array}{c}0.174 * * * \\
(0.066)\end{array}$ & $\begin{array}{c}0.168 * * * \\
(0.031)\end{array}$ & $\begin{array}{l}0.061 \\
(0.040)\end{array}$ & $\begin{array}{c}0.307 * * * \\
(0.097)\end{array}$ & $\begin{array}{c}0.178^{* * *} \\
(0.045)\end{array}$ & $\begin{array}{c}-0.184 * * * \\
(0.055)\end{array}$ & & $\begin{array}{l}0.097 \\
(0.076)\end{array}$ \\
\hline Avg. Adult Education (16-65 years old) & $\begin{array}{c}0.071 * * * \\
(0.009)\end{array}$ & $\begin{array}{c}0.047 * * * \\
(0.013)\end{array}$ & $\begin{array}{c}0.042 * * * \\
(0.005)\end{array}$ & $\begin{array}{c}0.028 * * * \\
(0.010)\end{array}$ & $\begin{array}{c}-0.025^{* * * *} \\
(0.006)\end{array}$ & $\begin{array}{c}0.030 * * * \\
(0.007)\end{array}$ & $\begin{array}{c}0.054 * * * \\
(0.014)\end{array}$ & $\begin{array}{c}0.018 * * \\
(0.007)\end{array}$ & $\begin{array}{c}-0.026^{* * * *} \\
(0.009)\end{array}$ & $\begin{array}{l}0.015 \\
(0.010)\end{array}$ & $\begin{array}{l}-0.001 \\
(0.013)\end{array}$ \\
\hline Age (HH Head) & $\begin{array}{c}0.035^{* * * *} \\
(0.009)\end{array}$ & $\begin{array}{c}0.080 * * * \\
(0.010)\end{array}$ & $\begin{array}{c}0.059^{* * * *} \\
(0.005)\end{array}$ & $\begin{array}{c}0.031 * * * \\
(0.010)\end{array}$ & $\begin{array}{c}0.039 * * * \\
(0.005)\end{array}$ & $\begin{array}{c}0.077 * * * \\
(0.007)\end{array}$ & $\begin{array}{c}0.048^{* * *} \\
(0.014)\end{array}$ & $\begin{array}{c}0.034^{* * *} \\
(0.007)\end{array}$ & $\begin{array}{c}0.030^{* * *} \\
(0.006)\end{array}$ & $\begin{array}{c}0.045^{* * *} \\
(0.012)\end{array}$ & $\begin{array}{l}0.017 \\
(0.012)\end{array}$ \\
\hline Age Squared x 100 (HH Head) & $\begin{array}{c}-0.031^{* * *} \\
(0.008)\end{array}$ & $\begin{array}{c}-0.082 * * * \\
(0.011)\end{array}$ & $\begin{array}{c}-0.063^{* * *} \\
(0.005)\end{array}$ & $\begin{array}{c}-0.034 * * * \\
(0.010)\end{array}$ & $\begin{array}{c}-0.043^{* * *} \\
(0.005)\end{array}$ & $\begin{array}{c}-0.078 * * * \\
(0.007)\end{array}$ & $\begin{array}{c}-0.052^{* * *} \\
(0.014)\end{array}$ & $\begin{array}{c}-0.037 * * * \\
(0.007)\end{array}$ & $\begin{array}{c}-0.032 * * * \\
(0.006)\end{array}$ & $\begin{array}{c}-0.049 * * * \\
(0.011)\end{array}$ & $\begin{array}{c}-0.026^{* *} \\
(0.011)\end{array}$ \\
\hline Years of Education (HH Head) & $\begin{array}{c}0.040 * * * \\
(0.007)\end{array}$ & $\begin{array}{c}0.036 * * * \\
(0.011)\end{array}$ & $\begin{array}{c}0.015 * * * \\
(0.005)\end{array}$ & $\begin{array}{l}0.013 \\
(0.010)\end{array}$ & $\begin{array}{l}-0.003 \\
(0.005)\end{array}$ & $\begin{array}{c}-0.031^{* * *} \\
(0.006)\end{array}$ & $\begin{array}{c}-0.046 * * * \\
(0.011)\end{array}$ & $\begin{array}{c}-0.013^{*} \\
(0.007)\end{array}$ & $\begin{array}{l}-0.008 \\
(0.007)\end{array}$ & $\begin{array}{c}-0.019 * * \\
(0.008)\end{array}$ & $\begin{array}{c}-0.028 * * * \\
(0.010)\end{array}$ \\
\hline HH Asset Index & $\begin{array}{c}-0.154^{* * * *} \\
(0.018)\end{array}$ & $\begin{array}{c}-0.264 * * * \\
(0.043)\end{array}$ & $\begin{array}{c}-0.236 * * * \\
(0.017)\end{array}$ & $\begin{array}{c}-0.048^{*} \\
(0.027)\end{array}$ & & $\begin{array}{c}-0.200^{* * *} \\
(0.025)\end{array}$ & & & $\begin{array}{c}-0.221 * * * \\
(0.043)\end{array}$ & $\begin{array}{c}-0.192 * * * \\
(0.023)\end{array}$ & $\begin{array}{c}-0.169 * * * \\
(0.034)\end{array}$ \\
\hline \% Rem. Recipient HHs in County or Provinc & $\begin{array}{c}-3.790 * * * \\
(0.151)\end{array}$ & & $\begin{array}{c}-3.568 * * * \\
(0.199)\end{array}$ & $\begin{array}{c}-6.072 * * * \\
(0.540)\end{array}$ & $\begin{array}{c}-3.071^{* * *} \\
(0.331)\end{array}$ & $\begin{array}{c}-2.960 * * * \\
(0.220)\end{array}$ & $\begin{array}{c}-3.455 * * * \\
(1.258)\end{array}$ & $\begin{array}{c}-5.898 * * * \\
(1.006)\end{array}$ & & $\begin{array}{c}-8.845^{* * * *} \\
(0.659)\end{array}$ & $\begin{array}{c}-3.663 * * * \\
(0.351)\end{array}$ \\
\hline \% Rem. Recipient HHs * HH Asset Index & $\begin{array}{r}-0.104 \\
(0.083)\end{array}$ & $\begin{array}{l}1.801 \\
(1.385)\end{array}$ & $\begin{array}{l}0.037 \\
(0.064)\end{array}$ & $\begin{array}{c}-0.283 \\
(0.280)\end{array}$ & & $\begin{array}{l}0.046 \\
(0.093)\end{array}$ & & & $\begin{array}{c}0.282 * * \\
(0.125)\end{array}$ & $\begin{array}{c}0.765^{* * *} \\
(0.221)\end{array}$ & $\begin{array}{c}0.240^{*} \\
(0.138)\end{array}$ \\
\hline \% Rem. Recipient HHs * Number 16-65 males & & & & & $\begin{array}{c}-0.915^{* * *} \\
(0.163)\end{array}$ & & $\begin{array}{c}-2.668 * * * \\
(0.732)\end{array}$ & $\begin{array}{c}-4.395^{* * *} \\
(0.615)\end{array}$ & & & \\
\hline Department/Province Indicators & Yes & Yes & Yes & Yes & Yes & Yes & Yes & Yes & Yes & Yes & Yes \\
\hline Observations & 16134 & 7009 & 15285 & 9400 & 21412 & 9565 & 5492 & 18188 & 7043 & 18226 & 4041 \\
\hline Pseudo R-Squared & 0.3530 & 0.1691 & 0.2485 & 0.2110 & 0.1939 & 0.2782 & 0.2837 & 0.1935 & 0.2363 & 0.3081 & 0.2661 \\
\hline
\end{tabular}

*Significant at $10 \%$ level. ${ }^{* *}$ Significant at 5\%level. ***Significant at $1 \%$ level. 
Having reviewed the results of the auxiliary regressions we are now in a position to present the results of our poverty simulations, which are reported in Tables 4 to 7. As noted above, our analysis is based on headcount poverty indexes, and it employs four poverty lines. In tables 4 and 5 we use internationally comparable poverty lines of US\$1 and US\$2 per person per day, measured at PPP values, which correspond respectively to "extreme" and "moderate" poverty rates. In tables 6 and 7 we base our analysis on nationally defined "extreme" and "moderate" poverty lines. Readers interested in country comparisons should probably be more concerned with the results of tables 4 and 5 whereas readers with interest in a specific country should focus on tables 6 and 7.

Before proceeding, it must be noted that some authors (Schiff, 2006) have proposed to complement the analysis of the effect of remittances on national poverty rates, by estimating their impact on the poverty rate prevailing among the subset of households which receive remittances. Their point is that while the impact of remittances on national poverty levels may be limited, the effect on the poverty status of the households with migrants could be much larger and therefore this restricted analysis can highlight a number of interesting facts for the corresponding sub-group of the population. Thus in the tables below we also report poverty effects using Schiff's approach.

Each table has two panels. Panel A reports: (i) the national headcount poverty rate according to the relevant poverty line; (ii) the poverty rate prevailing among remittances recipient households. Panel B reports: (i) the difference between the national poverty rate calculated using non-remittances household income and the observed poverty rate; (ii) the same calculation as in (i) for the specific sample of remittances recipient households; (iii) the difference between the national poverty rate calculated using counterfactual household income in the scenario of no migration nor remittances correcting for selectivity and change in household size; (iv) the same calculation as in (iii) for the specific sample of remittances recipient households. ${ }^{5}$

\footnotetext{
${ }^{5}$ While the results presented in the last two columns of panel B in tables 4 to 7 are our preferred estimates, estimated poverty effects of remittances calculated without correcting for selectivity or changes in household size can be found in an appendix available from the authors upon request. Those results may be relevant for readers interested in assessing the separate impact on the results based on counterfactual income estimates, of correcting first for selectivity and second for changes in household size.
} 
Table 4. Impact of remittances on headcount poverty (US\$1 PPP)

Panel A: Observed Poverty Rates

\begin{tabular}{|l|c|c|}
\hline \multirow{2}{*}{ Country } & All Households & Recipient HHs \\
\cline { 2 - 3 } & $(1)$ & $(2)$ \\
\hline Bolivia & 17.8 & 8.6 \\
\hline Dominican Republic & 4.7 & 3.3 \\
\hline Ecuador & 11.2 & 3.0 \\
\hline El Salvador & 7.7 & 2.8 \\
\hline Guatemala & 21.6 & 10.3 \\
\hline Haiti & 53.4 & 32.2 \\
\hline Honduras & 16.2 & 2.8 \\
\hline Mexico & 3.2 & 3.6 \\
\hline Nicaragua & & \\
\hline Paraguay & 6.3 & 4.7 \\
\hline Peru & & 4.0 \\
\hline
\end{tabular}

Panel B: Estimated Poverty Effects of Remittances with and without Adjustment for Lost Income

\begin{tabular}{|c|c|c|c|c|}
\hline \multirow[t]{2}{*}{ Country } & $\begin{array}{c}\text { Without } \\
\text { adjustment (all } \\
\text { HHs) }\end{array}$ & $\begin{array}{c}\text { Without } \\
\text { adjustment } \\
\text { (recipient HHs) }\end{array}$ & $\begin{array}{c}\text { With adjustment } \\
\text { (all HHs) }\end{array}$ & $\begin{array}{l}\text { With adjustment } \\
\text { (recipient } \mathrm{HHs} \text { ) }\end{array}$ \\
\hline & (1) & (2) & (3) & (4) \\
\hline Bolivia & -0.6 & -18.5 & $\begin{array}{c}-0.2 \\
(-0.4 ;-0.1)\end{array}$ & $\begin{array}{c}-6.7 \\
(-11.6 ;-1.8)\end{array}$ \\
\hline Dominican Republic & -2.5 & -11.1 & $\begin{array}{c}0.4 \\
(0.2 ; 0.5)\end{array}$ & $\begin{array}{c}1.6 \\
(1.0 ; 2.1)\end{array}$ \\
\hline Ecuador & -1.3 & -20.0 & $\begin{array}{c}-0.3 \\
(-0.4 ;-0.2) \\
\end{array}$ & $\begin{array}{c}-4.4 \\
(-5.8 ;-3.0) \\
\end{array}$ \\
\hline El Salvador & -4.4 & -23.0 & $\begin{array}{c}-0.5 \\
(-0.6 ;-0.3)\end{array}$ & $\begin{array}{c}-2.4 \\
(-3.2 ;-1.7)\end{array}$ \\
\hline Guatemala & -2.2 & -23.5 & $\begin{array}{c}-1.0 \\
(-1.3 ;-0.7) \\
\end{array}$ & $\begin{array}{c}-10.7 \\
(-14.0 ;-7.4) \\
\end{array}$ \\
\hline Haiti & -6.8 & -24.9 & $\begin{array}{c}-4.1 \\
(-4.7 ;-3.5) \\
\end{array}$ & $\begin{array}{c}-15.0 \\
(-17.4 ;-12.6) \\
\end{array}$ \\
\hline Honduras & -2.5 & -23.2 & $\begin{array}{c}-0.6 \\
(-0.7 ;-0.5) \\
\end{array}$ & $\begin{array}{c}-5.5 \\
(-6.5 ;-4.5) \\
\end{array}$ \\
\hline Mexico & -2.1 & -36.1 & $\begin{array}{c}0.1 \\
(0.0 ; 0.2)\end{array}$ & $\begin{array}{c}1.8 \\
(0.8 ; 2.8)\end{array}$ \\
\hline Nicaragua & -0.5 & -2.9 & $\begin{array}{c}0.0 \\
(-0.1 ; 0.1)\end{array}$ & $\begin{array}{c}0.1 \\
(-0.7 ; 0.9)\end{array}$ \\
\hline Paraguay & -0.8 & -20.4 & $\begin{array}{c}0.0 \\
(-0.1 ; 0.1)\end{array}$ & $\begin{array}{c}-0.2 \\
(-2.1 ; 1.8)\end{array}$ \\
\hline Peru & 0.0 & -0.7 & $\begin{array}{c}0.0 \\
(0.0 ; 0.0)\end{array}$ & $\begin{array}{c}-0.4 \\
(--0.7 ; 0.0)\end{array}$ \\
\hline
\end{tabular}


Table 5. Impact of remittances on headcount poverty (US\$2 PPP)

\begin{tabular}{|c|c|c|}
\hline Country & All Households & Recipient HHs \\
\hline & (1) & (2) \\
\hline Bolivia & 34.7 & 22.2 \\
\hline Dominican Republic & 12.8 & 7.4 \\
\hline Ecuador & 27.2 & 10.9 \\
\hline El Salvador & 18.6 & 10.8 \\
\hline Guatemala & 39.1 & 21.3 \\
\hline Haiti & 71.4 & 53.0 \\
\hline Honduras & 31.7 & 10.1 \\
\hline Mexico & 12.7 & 15.9 \\
\hline Nicaragua & 22.6 & 13.4 \\
\hline Paraguay & 15.3 & 14.1 \\
\hline Peru & 15.5 & 0.8 \\
\hline
\end{tabular}

Panel B: Estimated Poverty Effects of Remittances with and without Adjustment for Lost Income

\begin{tabular}{|c|c|c|c|c|}
\hline Country & $\begin{array}{c}\text { Without } \\
\text { adjustment (all } \\
\mathrm{HHs})\end{array}$ & $\begin{array}{c}\text { Without } \\
\text { adjustment } \\
\text { (recipient HHs) }\end{array}$ & $\begin{array}{c}\text { With adjustment } \\
\text { (all HHs) }\end{array}$ & $\begin{array}{l}\text { With adjustment } \\
\text { (recipient } \mathrm{HHs} \text { ) }\end{array}$ \\
\hline & (1) & (2) & (3) & (4) \\
\hline Bolivia & -0.6 & -17.1 & $\begin{array}{c}-0.4 \\
(-0.6 ;-0.1) \\
\end{array}$ & $\begin{array}{c}-10.6 \\
(-17.0 ;-4.2) \\
\end{array}$ \\
\hline Dominican Republic & -3.2 & -14.2 & $\begin{array}{c}-0.2 \\
(-0.3 ;-0.1) \\
\end{array}$ & $\begin{array}{c}-0.4 \\
(-1.5 ; 0.6) \\
\end{array}$ \\
\hline Ecuador & -1.7 & -25.7 & $\begin{array}{c}-0.8 \\
(-0.9 ;-0.6) \\
\end{array}$ & $\begin{array}{c}-12.0 \\
(-14.5 ;-9.6) \\
\end{array}$ \\
\hline El Salvador & -5.1 & -26.6 & $\begin{array}{c}-1.4 \\
(-1.6 ;-1.1) \\
\end{array}$ & $\begin{array}{c}-7.2 \\
(-8.5 ;-5.9) \\
\end{array}$ \\
\hline Guatemala & -2.2 & -23.4 & $\begin{array}{c}-1.6 \\
(-2.0 ;-1.3) \\
\end{array}$ & $\begin{array}{c}-17.0 \\
(-20.9 ;-13.2) \\
\end{array}$ \\
\hline Haiti & -4.9 & -18.0 & $\begin{array}{c}-3.0 \\
(-3.6 ;-2.4) \\
\end{array}$ & $\begin{array}{c}-10.9 \\
(-13.1 ;-8.7) \\
\end{array}$ \\
\hline Honduras & -3.0 & -27.9 & $\begin{array}{c}-1.5 \\
(-1.7 ;-1.4) \\
\end{array}$ & $\begin{array}{c}-13.8 \\
(-15.3 ;-12.3) \\
\end{array}$ \\
\hline Mexico & -2.3 & -40.1 & $\begin{array}{c}0.1 \\
(-0.1 ; 0.3) \\
\end{array}$ & $\begin{array}{c}3.0 \\
(0.9 ; 5.1) \\
\end{array}$ \\
\hline Nicaragua & -0.9 & -5.7 & $\begin{array}{c}-0.3 \\
(-0.5 ;-0.1) \\
\end{array}$ & $\begin{array}{c}-2.0 \\
(-3.4 ;-0.6) \\
\end{array}$ \\
\hline Paraguay & -0.9 & -22.3 & $\begin{array}{c}0.0 \\
(-0.2 ; 0.1)\end{array}$ & $\begin{array}{c}-0.7 \\
(-4.2 ; 2.8)\end{array}$ \\
\hline Peru & -0.1 & -5.2 & $\begin{array}{c}0.0 \\
(-0.1 ; 0.0)\end{array}$ & $\begin{array}{c}-0.6 \\
(-1.7 ; 0.5)\end{array}$ \\
\hline
\end{tabular}


Table 6. Impact of remittances on headcount poverty (nationally defined extreme poverty line)

Panel A: Observed Poverty Rates

\begin{tabular}{|l|c|c|}
\hline \multirow{2}{*}{ Country } & All Households & Recipient HHs \\
\cline { 2 - 3 } & $(1)$ & $(2)$ \\
\hline Bolivia & 37.5 & 26.4 \\
\hline Dominican Republic & 21.7 & 12.8 \\
\hline Ecuador & 25.8 & 10.4 \\
\hline El Salvador & 17.7 & 10.3 \\
\hline Guatemala & 32.1 & 18.8 \\
\hline Haiti & 85.4 & 70.3 \\
\hline Honduras & 36.0 & 13.5 \\
\hline Mexico & 22.2 & 28.7 \\
\hline Nicaragua & 34.3 & 18.3 \\
\hline Paraguay & 23.1 & 21.6 \\
\hline Peru & & 1.8 \\
\hline
\end{tabular}

Panel B: Estimated Poverty Effects of Remittances with and without Adjustment for Lost Income

\begin{tabular}{|c|c|c|c|c|}
\hline \multirow[t]{2}{*}{ Country } & $\begin{array}{c}\text { Without } \\
\text { adjustment (all } \\
\mathrm{HHs} \text { ) }\end{array}$ & $\begin{array}{c}\text { Without } \\
\text { adjustment } \\
\text { (recipient HHs) }\end{array}$ & $\begin{array}{c}\text { With adjustment } \\
\text { (all HHs) }\end{array}$ & $\begin{array}{l}\text { With adjustment } \\
\text { (recipient } \mathrm{HHs} \text { ) }\end{array}$ \\
\hline & (1) & (2) & (3) & (4) \\
\hline Bolivia & -0.6 & -17.5 & $\begin{array}{c}-0.3 \\
(-0.5 ;-0.1)\end{array}$ & $\begin{array}{c}-9.2 \\
(-15.8 ;-2-6)\end{array}$ \\
\hline Dominican Republic & -3.8 & -16.6 & $\begin{array}{c}-0.5 \\
(-0.9 ;-0.2)\end{array}$ & $\begin{array}{c}-2.4 \\
(-3.8 ;-1.0)\end{array}$ \\
\hline Ecuador & -1.7 & -25.8 & $\begin{array}{c}-0.7 \\
(-0.9 ;-0.6)\end{array}$ & $\begin{array}{c}-11.1 \\
(-13.4 ;-8.8)\end{array}$ \\
\hline El Salvador & -5.0 & -26.1 & $\begin{array}{c}-1.3 \\
(-1.5 ;-1.0)\end{array}$ & $\begin{array}{c}-6.5 \\
(-7.8 ;-5.2)\end{array}$ \\
\hline Guatemala & -2.0 & -21.3 & $\begin{array}{c}-1.3 \\
(-1.6 ;-0.9)\end{array}$ & $\begin{array}{c}-13.3 \\
(-17.1 ;-9.5)\end{array}$ \\
\hline Haiti & -4.2 & -15.5 & $\begin{array}{c}-2.6 \\
(-3.1 ;-2.0)\end{array}$ & $\begin{array}{c}-9.4 \\
(-11.5 ;-7.3)\end{array}$ \\
\hline Honduras & -3.1 & -28.3 & $\begin{array}{c}-1.7 \\
(-1.8 ;-1.5)\end{array}$ & $\begin{array}{c}-15.1 \\
(-16.6 ;-13.6)\end{array}$ \\
\hline Mexico & -2.1 & -36.4 & $\begin{array}{c}0.1 \\
(0.0 ; 0.3)\end{array}$ & $\begin{array}{c}2.4 \\
(-0.3 ; 5.2)\end{array}$ \\
\hline Nicaragua & -0.8 & -5.2 & $\begin{array}{c}-0.2 \\
(-0.5 ; 0.0)\end{array}$ & $\begin{array}{c}-1.6 \\
(-3.2 ; 0.0)\end{array}$ \\
\hline Paraguay & -0.9 & -24.2 & $\begin{array}{c}-0.1 \\
(-0.3 ; 0.0)\end{array}$ & $\begin{array}{c}-3.1 \\
(-7.4 ; 1.1)\end{array}$ \\
\hline Peru & -0.2 & -6.7 & $\begin{array}{c}0.0 \\
(-0.1 ; 0.0)\end{array}$ & $\begin{array}{c}-1.1 \\
(-2.6 ;-0.5)\end{array}$ \\
\hline
\end{tabular}


Table 7. Impact of remittances on headcount poverty (nationally defined moderate poverty line)

Panel A: Observed Poverty Rates

\begin{tabular}{|l|c|c|}
\hline \multirow{2}{*}{ Country } & All Households & Recipient HHs \\
\cline { 2 - 3 } & $(1)$ & $(2)$ \\
\hline Bolivia & 61.3 & 44.9 \\
\hline Dominican Republic & 50.0 & 37.7 \\
\hline Ecuador & 52.6 & 32.0 \\
\hline El Salvador & 38.7 & 32.8 \\
\hline Guatemala & 58.8 & 44.6 \\
\hline Haiti & 94.5 & 88.1 \\
\hline Honduras & 57.0 & 34.2 \\
\hline Mexico & 28.0 & 35.7 \\
\hline Nicaragua & 58.9 & 37.2 \\
\hline Paraguay & 47.0 & 48.2 \\
\hline Peru & & 9.2 \\
\hline
\end{tabular}

Panel B: Estimated Poverty Effects of Remittances with and without Adjustment for Lost Income

\begin{tabular}{|c|c|c|c|c|}
\hline Country & $\begin{array}{c}\text { Without } \\
\text { adjustment (all } \\
\mathrm{HHs} \text { ) }\end{array}$ & $\begin{array}{c}\text { Without } \\
\text { adjustment } \\
\text { (recipient HHs) }\end{array}$ & $\begin{array}{c}\text { With adjustment } \\
\text { (all HHs) }\end{array}$ & $\begin{array}{l}\text { With adjustment } \\
\text { (recipient } \mathrm{HHs} \text { ) }\end{array}$ \\
\hline & (1) & $(2)$ & (3) & (4) \\
\hline Bolivia & -0.5 & -15.2 & $\begin{array}{c}-0.4 \\
(-0.7 ;-0.2)\end{array}$ & $\begin{array}{c}-7.2 \\
(-11.7 ;-2.8)\end{array}$ \\
\hline Dominican Republic & -4.0 & -17.4 & $\begin{array}{c}-0.8 \\
(-1.2 ;-0.3)\end{array}$ & $\begin{array}{c}-3.3 \\
(-5.3 ;-1.3)\end{array}$ \\
\hline Ecuador & -1.8 & -27.8 & $\begin{array}{c}-1.0 \\
(-1.2 ;-0.8)\end{array}$ & $\begin{array}{c}-15.4 \\
(-18.5 ;-12.3) \\
\end{array}$ \\
\hline El Salvador & -4.3 & -22.3 & $\begin{array}{c}-1.3 \\
(-1.6 ;-1.0) \\
\end{array}$ & $\begin{array}{c}-6.7 \\
(-8.3 ;-5.0)\end{array}$ \\
\hline Guatemala & -1.8 & -18.3 & $\begin{array}{c}-0.9 \\
(-1.3 ;-0.5)\end{array}$ & $\begin{array}{c}-9.2 \\
(-13.1 ;-5.3) \\
\end{array}$ \\
\hline Haiti & -2.0 & -7.3 & $\begin{array}{c}-0.4 \\
(-0.8 ; 0.1)\end{array}$ & $\begin{array}{c}-1.4 \\
(-3.1 ; 0.3) \\
\end{array}$ \\
\hline Honduras & -3.0 & -27.2 & $\begin{array}{c}-2.1 \\
(-2.3 ;-1.9) \\
\end{array}$ & $\begin{array}{c}-19.1 \\
(-20.7 ;-17.5) \\
\end{array}$ \\
\hline Mexico & -2.0 & -33.7 & $\begin{array}{c}0.1 \\
(-0.1 ; 0.3) \\
\end{array}$ & $\begin{array}{c}1.4 \\
(-1.5 ; 4.3)\end{array}$ \\
\hline Nicaragua & -0.8 & -5.4 & $\begin{array}{c}-0.7 \\
(-1.0 ;-0.4) \\
\end{array}$ & $\begin{array}{c}-4.3 \\
(-6-2 ;-2.4)\end{array}$ \\
\hline Paraguay & -0.7 & -17.9 & $\begin{array}{c}-0.2 \\
(-0.4 ; 0.1)\end{array}$ & $\begin{array}{c}-4.0 \\
(-9.6 ; 1.5)\end{array}$ \\
\hline Peru & -0.4 & -13.5 & $\begin{array}{c}-0.1 \\
(-0.2 ; 0.0)\end{array}$ & $\begin{array}{c}-3.0 \\
(-5.9 ;-0.1) \\
\end{array}$ \\
\hline
\end{tabular}


The first element to note in this analysis is that nationally defined poverty lines tend to yield higher poverty rates than those based on the PPP adjusted US\$1 and US\$2 lines. This reflects the fact that countries tend to use more inclusive definitions of poverty (in the sense that more people qualify). These differences between nationally and internationally defined poverty lines are such that extreme poverty rates calculated using local poverty lines tend to be higher than the corresponding internationally defined moderate poverty rates (i.e. US\$2). It should not then be surprising that the use of one or another set of poverty lines produces results that from a numerical point of view can vary significantly for each country.

Also worthy of note is the fact that poverty rates observed among households with migrants tend to be lower than those found in the general population. In Peru and Nicaragua, for instance, national poverty levels based on the US\$2 poverty line had been estimated to be close to 16 and 27 percent respectively, but they are close to 1 and 13 percent among recipients of remittances. Other countries where households with migrants are considerably less likely to be poor than the average household in the country include Bolivia, Ecuador, Guatemala, Haiti and Honduras. The exception to this rule is Mexico where regardless of the poverty line being considered poverty rates are higher among households receiving remittances than in the general population.

As for the impact of remittances on poverty, column (1) in panel B of tables 4 to 7 report the absolute change in poverty rates - measured in percentage points - when remittances are added to the other components of household income, without taking into consideration possible reductions in household income following the migration of family members. It is as if we were comparing observed poverty rates with those prevailing in a counterfactual scenario where migration did take place but no money was remitted to family members left behind. With this approach, the results suggest that in the Dominican Republic, Guatemala, Honduras, Haiti, El Salvador and Mexico remittances cause reductions in moderate and extreme poverty headcounts ranging from 2 to 7 percentage points - both using national and international poverty lines. At least in the two latter countries, this does not come as a surprise given that households with migrants tend to come from the lowest quintiles of the income distribution.

In contrast to the above results, the estimated reductions in poverty due to remittances receipts become much lower when observed poverty rates are compared to those prevailing in a less simplistic scenario where neither remittances nor migration are present. Thus, the results in column (3) of Panel B in the tables below suggest that given the demographic characteristics of recipient households, their income in the event of no migration would have been higher than observed non-remittances income. As a result, the poverty reducing effects of remittances become much smaller. As an example, for El Salvador, Guatemala and Honduras, we now estimate reductions in poverty headcounts of between 1 and 2 percentage points, and in Haiti the reductions are of between 3 and 4 percentage in three out of four cases. The effects are even smaller for other countries. Moreover, in the case Mexico we now find that remittances either have not a significant poverty reducing effect or are tied to a small increase of 0.1 percentage points in poverty rates. ${ }^{6}$

\footnotetext{
${ }^{6}$ The (very small) poverty-increasing remittances effects obtained for Mexico suggest that remittances do not compensate for the fall in income associated with migration. This is to some extent counter-intuitive and could be due to the presence of unobserved characteristics that reduce households' income generation capacity and increase
} 
It is not trivial to establish a common pattern to describe the set of countries where the largest poverty reductions are obtained. The position of migrants' households in the income distribution does seem to play a role, as is illustrated by the fact that neither Peru nor Nicaragua - where remittances tend to flow towards the highest income quintiles - are in the group of countries with the highest reductions in poverty rates are obtained. However, the countries where the largest shares of recipients are found to be in the bottom quintiles - Mexico and Paraguay do not belong to that group either. One possible explanation is that in these two countries the share of remittances receiving households is relatively low - respectively 5.8 and 3.8 percent of the population - and so is the dollar amount of remittances received by households, as measured by the share of those flows in GDP - 1.6 and 3.5 percent respectively. Moreover, remittances per household as a proportion of the country's per capita income are among the lowest in Mexico: 47 percent, compared to 140 percent on average among the five above mentioned countries where the highest reductions in poverty are obtained.

As illustrated in the last column of tables 4 to 7 the poverty reducing effects of remittances on the prevalence of poverty are larger in the subset of the population made up of recipient households. As an example, in Bolivia, Ecuador, Guatemala, Haiti and Honduras moderate poverty rates in that specific subgroup of the population are found to fall by between 10 and 17 percentage points, when using international poverty lines. Thus, it is clear that even if the impact of remittances on national poverty rates is found to be relatively modest in most countries, remittances do seem to have an important poverty reducing effect on the pool of poor households with migrants.

\section{Remittances and Human Capital}

The previous section has explored the effects that remittances can have on household income and poverty. However, remittances can also affect the long term welfare of recipients by means of affecting human capital formation. Exploring this possibility is important for at least two main reasons. First, one could see the effects of remittances on the health and educational outcomes of recipient households as complementing the analysis of the monetary dimensions of poverty. Second, through its effects on human capital remittances can have lagged effects on household income and consequently on monetary defined poverty indexes. For example, if children in recipient households accumulate more (or better) human capital than otherwise similar kids, then remittances can also be expected to positively affect long run growth and hence long run poverty levels. This section explores these issues.

their willingness to migrate - e.g. persistent unemployment, bad crops, etc.. If this negative selection into migration driven by unobservable household characteristics prevails over positive selection effects, one could end up overestimating households' counterfactual income prior to migration. An alternative explanation could be linked to the possible under-reporting of remittances income. 


\section{IV.1. Educational Attainment}

The net impact of migration and remittances on human capital accumulation is a priori unclear. On one hand, migrant remittances can help overcome borrowing constraints that limit physical and human capital investments of poor households. On the other hand, migration of household members that precedes the receipt of remittances can have disruptive effects on family life, with potentially negative consequences on the educational attainment of children. Moreover, to the extent that in destination countries most migrants tend to work in occupations requiring limited schooling, the returns from investments in education may be lower for those that are envisaging international migration, which also could tend to reduce the schooling of children in migrants' households. Similarly, migration can put pressure on wages at the home country, raising the opportunity cost of not working for older children. In any case, the direction of the relationship between remittances and child education would depend on idiosyncratic characteristics of each country.

Existing evidence on the impact of remittances on education in LAC is restricted to Mexico and El Salvador. Hanson and Woodruff (2003) find that remittances are associated with higher educational attainment in rural Mexico, in particular among 10-15 year old girls whose mothers have low educational levels. Lopez-Cordova (2005) shows that higher remittance flows are associated with lower illiteracy rates in Mexican municipalities, but the evidence on the impact on school attendance is mixed: the effect is positive only for 5-year olds, becoming insignificant among 6-14 years old and negative for those aged 15 to 17. McKenzie and Rapoport (2006), again for Mexico, show that children aged 16 to 18 from households with migrants exhibit lower educational attainment levels, and that this negative effect is larger for those whose mothers have higher levels of schooling. For the case of El Salvador, Cox-Edwards and Ureta (2003) show that children from remittance recipient households are less likely to drop out of school, which they attribute to the relaxation of budget constraints affecting poor recipient households. Acosta (2006) shows that this result is stronger for girls and younger boys in this country.

We would like to assess whether previous literature findings can apply to other countries in the region with significant remittances flows and available micro-data (Mexico, El Salvador, Nicaragua, Guatemala, Honduras, Haiti, Dominican Republic, Ecuador, Paraguay, Peru and Jamaica). ${ }^{7}$ Disparities in secondary enrollment rates are large in the LAC region, ranging from about 80 percent in countries such as Chile and Argentina, to less than 50 percent in countries like Mexico, El Salvador, the Dominican Republic, Nicaragua, Honduras, Guatemala and Haiti (Figure 4), which are also among the top international migrant remittances receivers in the region.

The claim that remittances could potentially have an important effect on education, by overcoming borrowing constraints and allowing higher investment in children education is illustrated by the comparison of enrollment rates among children aged 12 to 17 across recipient and non-recipient households (Figure 5). With the only exception of Mexico, children from

\footnotetext{
${ }^{7}$ Bolivia is excluded due to limited observations of children from remittance recipient households. Jamaica, not included in the previous section due to the lack of non-remittance income data in the corresponding survey, is included for the analysis of educational attainment.
} 
households reporting remittances are more likely to stay at school. The largest differences are obtained for Nicaragua, Guatemala and Honduras, where enrollment rates are between 12 and 17 percent higher for recipient households.

Figure 4. Average Years of Education for Adults (22-65 years old)

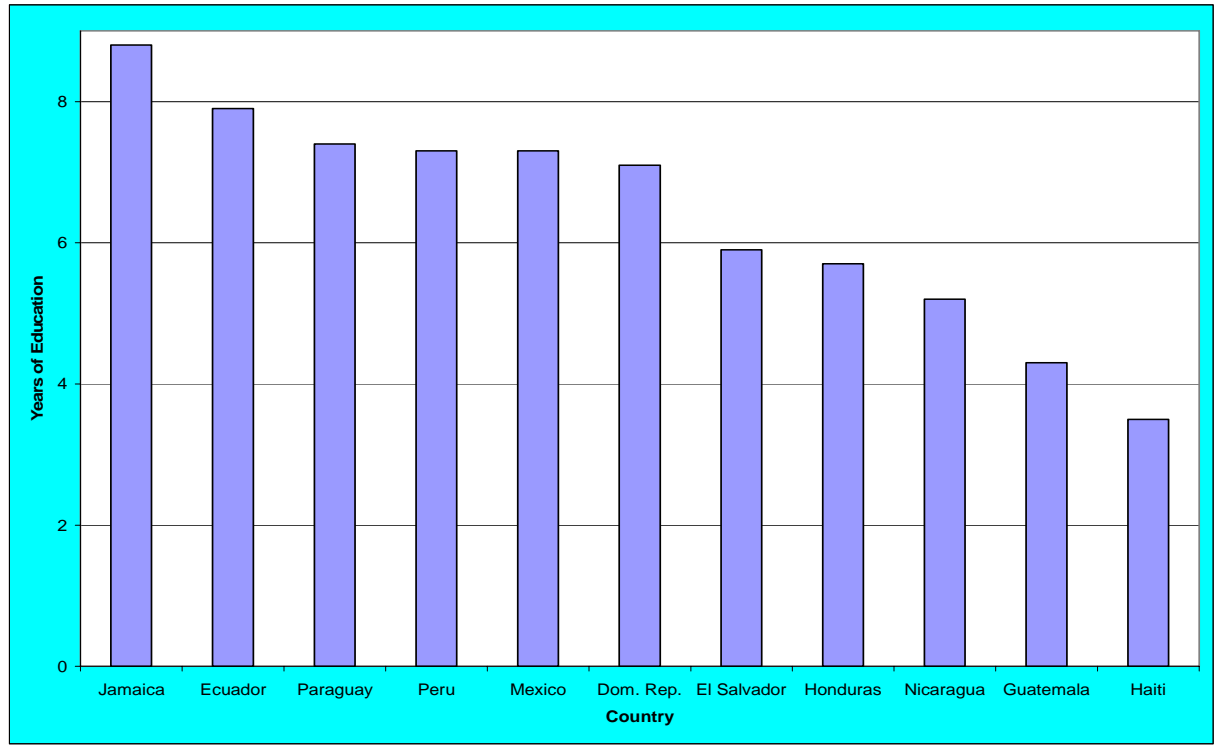

Source: Author's calculations based on household surveys.

Figure 5. Differences in School Enrollment Rates for 12-17 years old by Remittances Recipient Status

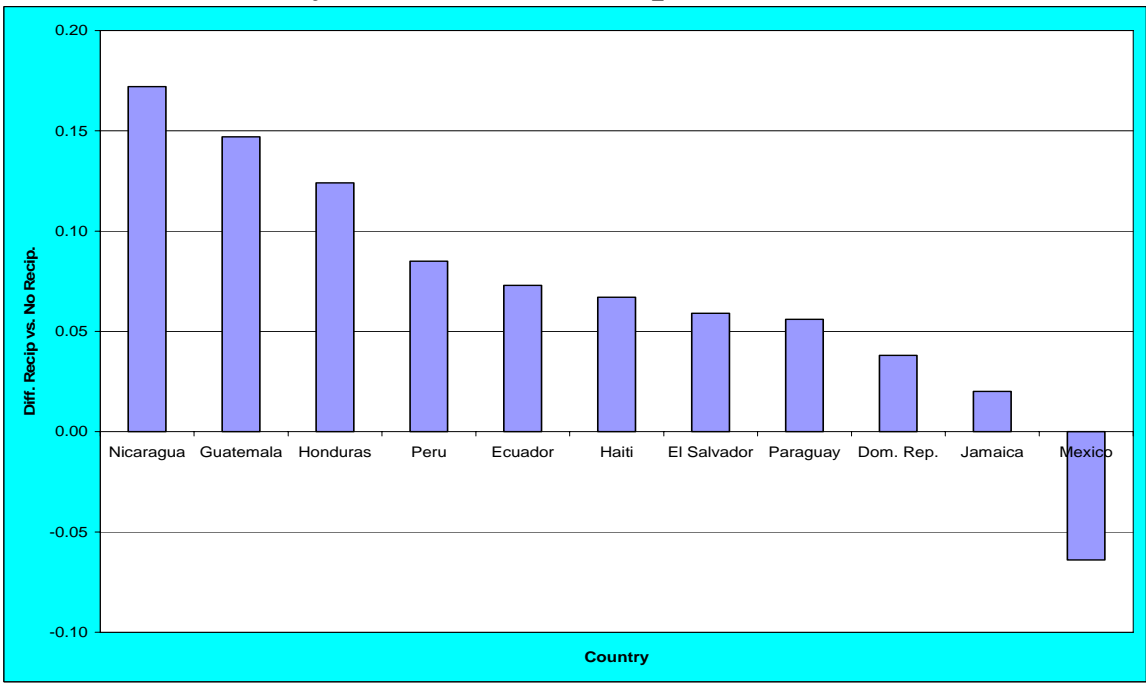

Source: Author's calculation based on household surveys.

Of course, some of these differences could be attributed to the fact that households receiving remittances can be systematically different from non-recipient counterparts. It is thus necessary to control for observable demographic differences in order to test the robustness of the estimated effects of remittances on human capital. In addition, to assess the effect of remittances and migration, the human capital of recipients should ideally be compared to households that had similar levels of income prior to migration. In this respect, we take advantage of the fact that 
in the previous section of this paper we estimated the income of remittances recipient households in that counterfactual scenario, to compare the educational attainment of their children with those of other households with similar social and economic conditions prior to migration - besides observed demographics. In particular, following a specification close to that in Hanson and Woodruff (2003), equation (4) below is estimated for children aged between 10 and 15 years old. We perform different estimations varying by gender and area of residence (urban and rural).

$$
E_{i}=\alpha+\beta X_{i}+\gamma M_{i}+\lambda C_{i}+\delta R_{i}+\varepsilon_{i}
$$

where $E_{i}$ represents the number of school grades completed by child $i$ and $X_{i}$ is a vector of child and household characteristics (age of the child, a dummy for the child being the oldest in the household, indicators for the number of children of different ages in the household, presence of a 0-5 year old child, family home ownership), including quintile indicators for the counterfactual income that migrant households would have had in the absence of migration. These quintiles are constructed by ranking households according to per capita income levels, after inputting counterfactual incomes for households reporting positive remittances according to the procedure described in Sections II and III. ${ }^{8}$ Equation (4) also includes a set $M_{i}$ of characteristics of the child's mother (indicators for mother's education, mother's marital status, mother's head of household status, and a quartic in mother's age). $C_{i}$ represents community characteristics (the proportion of households with sanitary services in the county of residence, the proportion of household heads working in agricultural activities in the county of residence, and state/province indicators), $R_{i}$ is a "dummy" variable for households that receive remittances (the sample also includes non-recipients), and $\varepsilon_{i}$ is a random error. Regression estimates for the $\delta$ coefficient on the main variable of interest, $R_{i}$, are presented in table 8 .

The results suggest that "access to remittances" is positively and significantly associated with higher educational attainment in 6 out of 11 countries - the exceptions being Mexico, Paraguay, Peru, Jamaica and the Dominican Republic. The estimated positive impact of remittances varies by gender and across rural and urban areas - e.g. in Ecuador an impact is found only for urban areas. Since the actual amount remitted is likely to have a differential impact depending on the magnitude of the transfer, we have also replicated this analysis looking at the impact of the per capita value of remittances received by the household. The results using this alternative measure for remittances suggest that higher flows also increase schooling in the Dominican Republic, and among boys in urban Mexico.

A potential methodological concern associated with the above results is that unobserved household characteristics that affect their propensity to have migrants and receive remittances could also be driving the decisions to keep children in school. We have attempted the use of instrumental variables to address this simultaneity bias, but have failed to find appropriate instruments that are sufficiently correlated with the migration status of households but do not otherwise affect the educational attainment of children. For instance, while variables such as the fraction of households that receive remittances in the county and its interaction with household characteristics have passed standard specification tests for instrumental variables, the fact that

\footnotetext{
${ }^{8}$ The regressions for Jamaica control for quintiles in counterfactual expenditure per capita rather than income per capita, due to the lack of non-remittances income information in the survey.
} 
the size of the sample of children aged 10 to 15 is relatively small has led coefficients and standard errors to increase considerably in comparison with ordinary least squares, leading us to focus on the latter, and rely on the assumption that controlling for parental schooling reduces the effect of unobservables household characteristics linked to human capital investments and migration - e.g. how much households value human capital.

Table 8. Access to Remittances and Children Education - OLS

\begin{tabular}{|c|c|c|c|c|}
\hline Age Group & \multicolumn{4}{|c|}{ 10-15 Years Old } \\
\hline Dependent Variable & \multicolumn{4}{|c|}{ Accumulated Schooling } \\
\hline \multirow{2}{*}{ Sample } & \multicolumn{2}{|c|}{ Rural } & \multicolumn{2}{|c|}{ Urban } \\
\hline & Boys & Girls & Boys & Girls \\
\hline Mexico & $\begin{array}{l}-0.149 \\
(0.129)\end{array}$ & $\begin{array}{l}0.113 \\
(0.095)\end{array}$ & $\begin{array}{l}-0.023 \\
(0.177)\end{array}$ & $\begin{array}{c}-0.235 \\
(0.192)\end{array}$ \\
\hline El Salvador & $\begin{array}{c}0.482^{* * *} \\
(0.110)\end{array}$ & $\begin{array}{c}0.312^{* * *} \\
(0.097)\end{array}$ & $\begin{array}{c}0.245^{* *} \\
(0.098)\end{array}$ & $\begin{array}{l}-0.010 \\
(0.097)\end{array}$ \\
\hline Guatemala & $\begin{array}{c}0.448 * * \\
(0.177)\end{array}$ & $\begin{array}{c}0.313^{*} \\
(0.164)\end{array}$ & $\begin{array}{l}0.291 \\
(0.230)\end{array}$ & $\begin{array}{c}0.454^{* *} \\
(0.177)\end{array}$ \\
\hline Honduras & $\begin{array}{c}0.427 * * * \\
(0.100)\end{array}$ & $\begin{array}{c}0.495 * * * \\
(0.098)\end{array}$ & $\begin{array}{c}0.298 * * * \\
(0.078)\end{array}$ & $\begin{array}{c}0.360 * * * \\
(0.080)\end{array}$ \\
\hline Ecuador & $\begin{array}{l}0.187 \\
(0.149)\end{array}$ & $\begin{array}{l}0.112 \\
(0.151)\end{array}$ & $\begin{array}{c}0.289 * * \\
(0.125)\end{array}$ & $\begin{array}{c}0.314^{* *} \\
(0.134)\end{array}$ \\
\hline Paraguay & $\begin{array}{l}-0.012 \\
(0.195)\end{array}$ & $\begin{array}{l}0.208 \\
(0.182)\end{array}$ & & \\
\hline Haiti & & & $\begin{array}{l}0.098 \\
(0.107)\end{array}$ & $\begin{array}{c}0.244 * * \\
(0.098)\end{array}$ \\
\hline Peru & & & $\begin{array}{l}-0.070 \\
(0.146)\end{array}$ & $\begin{array}{l}0.157 \\
(0.120)\end{array}$ \\
\hline Nicaragua $^{1}$ & $\begin{array}{c}0.437 * * * \\
(0.153)\end{array}$ & $\begin{array}{c}0.375 * * * \\
(0.133)\end{array}$ & & \\
\hline Jamaica $^{1}$ & $\begin{array}{c}-0.114 \\
(0.150)\end{array}$ & $\begin{array}{c}-0.005 \\
(0.113)\end{array}$ & & \\
\hline Dominican Republic ${ }^{1}$ & $\begin{array}{c}0.077 \\
(0.107)\end{array}$ & $\begin{array}{l}0.118 \\
(0.094)\end{array}$ & & \\
\hline
\end{tabular}

Notes: *** Significant at 1\% level. ** Significant at 5\% level.

* Significant at $10 \%$ level. ${ }^{1}$ Rural and Urban areas together.

The set of controls includes the age of the child, a dummy for the child being the oldest in the household, indicators for mother's education, mother's marital status, mother's head of household status, and a quartic in mother's age, indicators for the number of children of different ages in the household, presence of a 0-5 year old child, family home ownership, counterfactual income quintiles, the proportion of households with sanitary services in the county of residence, the proportion of household heads working in agricultural activities in the county of residence, and state/province indicators.

Source: Author's calculations based on household surveys

As mentioned at the beginning of the section, previous evidence on Mexico has suggested that the positive effects of remittances on schooling vary with the educational attainment of the children's' parents (Hanson and Woodruff, 2003; McKenzie and Rapoport, 2006), being generally larger when the latter are low. Differential effects of this sort could be due to the fact 
that among poorer households - with lower levels of adult schooling - remittances could have a more sizable effect in terms of relaxing budget constraints that keep children out of school. However, one could also expect an opposite effect - remittances having a smaller impact on education when the schooling of parents is low - if less educated parents exhibit lower preferences for educational over other alternative expenditures. To find out which effect dominates, we re-estimate equation (4) by adding an interaction term between remittances $\left(R_{i}\right)$ and a variable that indicates whether the mother has four of more years of education. The corresponding results are reported in table 9.

Table 9. Remittances and Children's Education by Mother's Education

\begin{tabular}{|c|c|c|c|c|c|}
\hline \multicolumn{2}{|l|}{ Age Group } & \multicolumn{4}{|c|}{ 10-15 Years Old } \\
\hline \multicolumn{2}{|c|}{ Dependent Variable } & \multicolumn{4}{|c|}{ Accumulated Schooling } \\
\hline \multirow{2}{*}{ Country } & \multirow{2}{*}{ Variable } & \multicolumn{2}{|c|}{ Rural } & \multicolumn{2}{|c|}{ Urban } \\
\hline & & Boys & Girls & Boys & Girls \\
\hline \multirow[t]{2}{*}{ Mexico } & Receive Remittances & $\begin{array}{l}-0.082 \\
(0.192)\end{array}$ & $\begin{array}{c}0.329 * * \\
(0.141)\end{array}$ & $\begin{array}{r}-0.041 \\
(0.329)\end{array}$ & $\begin{array}{l}-0.573 \\
(0.553)\end{array}$ \\
\hline & $\begin{array}{l}\text { Receive Remittances * } \\
\text { Mother Educ } 4 \text { Years or More }\end{array}$ & $\begin{array}{l}-0.144 \\
(0.240)\end{array}$ & $\begin{array}{c}-0.417 * * \\
(0.186)\end{array}$ & $\begin{array}{l}0.024 \\
(0.378)\end{array}$ & $\begin{array}{l}0.461 \\
(0.577)\end{array}$ \\
\hline \multirow[t]{2}{*}{ El Salvador } & Receive Remittances & $0.511 * * *$ & $0.251 * *$ & $0.365 * *$ & -0.191 \\
\hline & $\begin{array}{l}\text { Receive Remittances * } \\
\text { Mother Educ } 4 \text { Years or More }\end{array}$ & $\begin{array}{l}-0.116 \\
(0.212)\end{array}$ & $\begin{array}{l}0.229 \\
(0.176)\end{array}$ & $\begin{array}{l}-0.203 \\
(0.197)\end{array}$ & $\begin{array}{l}0.297 \\
(0.206)\end{array}$ \\
\hline \multirow[t]{2}{*}{ Guatemala } & Receive Remittances & $\begin{array}{l}0.482 * * \\
(0.200)\end{array}$ & $\begin{array}{l}0.223 \\
(0.186)\end{array}$ & $\begin{array}{l}0.412 \\
(0.337)\end{array}$ & $\begin{array}{l}1.109^{* * *} \\
(0.231)\end{array}$ \\
\hline & $\begin{array}{l}\text { Receive Remittances * } \\
\text { Mother Educ } 4 \text { Years or More }\end{array}$ & $\begin{array}{c}-0.179 \\
(0.389)\end{array}$ & $\begin{array}{l}0.450 \\
(0.318)\end{array}$ & $\begin{array}{l}-0.323 \\
(0.408)\end{array}$ & $\begin{array}{c}-1.336 * * * \\
(0.315)\end{array}$ \\
\hline \multirow[t]{2}{*}{ Honduras } & Receive Remittances & $\begin{array}{l}0.581^{* * *} \\
(0.142)\end{array}$ & $\begin{array}{l}0.662 * * * \\
(0.155)\end{array}$ & $\begin{array}{l}0.731^{* * *} \\
(0.178)\end{array}$ & $\begin{array}{l}0.554 * * * \\
(0.209)\end{array}$ \\
\hline & $\begin{array}{l}\text { Receive Remittances * } \\
\text { Mother Educ } 4 \text { Years or More }\end{array}$ & $\begin{array}{c}-0.317^{*} \\
(0.193)\end{array}$ & $\begin{array}{c}-0.328 * \\
(0.184)\end{array}$ & $\begin{array}{c}-0.564 * * * \\
(0.193)\end{array}$ & $\begin{array}{l}-0.247 \\
(0.220)\end{array}$ \\
\hline \multirow[t]{2}{*}{ Ecuador } & Receive Remittances & $\begin{array}{l}0.278 \\
(0.233)\end{array}$ & $\begin{array}{l}-0.106 \\
(0.237)\end{array}$ & $\begin{array}{l}0.502 \\
(0.331)\end{array}$ & $\begin{array}{c}0.805^{*} \\
(0.463)\end{array}$ \\
\hline & $\begin{array}{l}\text { Receive Remittances * } \\
\text { Mother Educ } 4 \text { Years or More }\end{array}$ & $\begin{array}{l}-0.138 \\
(0.277)\end{array}$ & $\begin{array}{l}0.386 \\
(0.287)\end{array}$ & $\begin{array}{l}-0.239 \\
(0.344)\end{array}$ & $\begin{array}{l}-0.547 \\
(0.475)\end{array}$ \\
\hline \multirow[t]{2}{*}{ Paraguay } & Receive Remittances & $\begin{array}{l}0.056 \\
(0.271)\end{array}$ & $\begin{array}{c}0.433^{*} \\
(0.235)\end{array}$ & & \\
\hline & $\begin{array}{l}\text { Receive Remittances * } \\
\text { Mother Educ } 4 \text { Years or More }\end{array}$ & $\begin{array}{r}-0.133 \\
(0.374) \\
\end{array}$ & $\begin{array}{l}-0.476 \\
(0.345) \\
\end{array}$ & & \\
\hline \multirow[t]{2}{*}{ Haiti } & Receive Remittances & & & $\begin{array}{l}0.043 \\
(0.120)\end{array}$ & $\begin{array}{l}0.273^{* *} \\
(0.111)\end{array}$ \\
\hline & $\begin{array}{l}\text { Receive Remittances * } \\
\text { Mother Educ } 4 \text { Years or More }\end{array}$ & & & $\begin{array}{l}0.229 \\
(0.237)\end{array}$ & $\begin{array}{r}-0.111 \\
(0.220)\end{array}$ \\
\hline \multirow[t]{2}{*}{ Peru } & Receive Remittances & & & $\begin{array}{l}0.187 \\
(0.296)\end{array}$ & $\begin{array}{l}0.393^{* * *} \\
\quad(0.144)\end{array}$ \\
\hline & $\begin{array}{l}\text { Receive Remittances * } \\
\text { Mother Educ } 4 \text { Years or More }\end{array}$ & & & $\begin{array}{r}-0.362 \\
(0.338)\end{array}$ & $\begin{array}{c}-0.343^{*} \\
(0.207)\end{array}$ \\
\hline \multirow[t]{2}{*}{ Nicaragua ${ }^{1}$} & Receive Remittances & $\begin{array}{c}0.577 * * \\
(0.260)\end{array}$ & $\begin{array}{c}0.554 * * \\
(0.221)\end{array}$ & & \\
\hline & $\begin{array}{l}\text { Receive Remittances * } \\
\text { Mother Educ } 4 \text { Years or More }\end{array}$ & $\begin{array}{l}-0.208 \\
(0.310) \\
\end{array}$ & $\begin{array}{l}-0.296 \\
(0.258) \\
\end{array}$ & & \\
\hline \multirow[t]{2}{*}{ Jamaica $^{1}$} & Receive Remittances & $\begin{array}{l}0.510 \\
(0.465)\end{array}$ & $\begin{array}{l}-0.236 \\
(0.435)\end{array}$ & & \\
\hline & $\begin{array}{l}\text { Receive Remittances * } \\
\text { Mother Educ } 4 \text { Years or More }\end{array}$ & $\begin{array}{l}-0.668 \\
(0.484) \\
\end{array}$ & $\begin{array}{l}0.253 \\
(0.443) \\
\end{array}$ & & \\
\hline \multirow[t]{2}{*}{ Dom. Rep. ${ }^{1}$} & Receive Remittances & $\begin{array}{r}-0.148 \\
(0.242)\end{array}$ & $\begin{array}{l}0.301 \\
(0.208)\end{array}$ & & \\
\hline & $\begin{array}{l}\text { Receive Remittances * } \\
\text { Mother Educ } 4 \text { Years or More }\end{array}$ & $\begin{array}{l}0.282 \\
(0.263)\end{array}$ & $\begin{array}{l}-0.242 \\
(0.230)\end{array}$ & & \\
\hline
\end{tabular}

${ }^{1}$ Rural and Urban areas together.

Regressions include the same set of controls as in Table 8.

Source: Author's calculations based on household surveys. 
Our findings confirm those of previous papers on Mexico, suggesting that the positive effect of remittances on education tends to be larger when parents' schooling is low. For instance, among rural girls in Mexico, Paraguay and Peru, ${ }^{9}$ our previous results suggested no effect of remittances on educational attainment but we now find a positive and significant effect for those whose mothers have at most three years of educational attainment, whereas for the remaining children the effect is estimated to be close to zero - although slightly negative in Mexico and Paraguay. Similarly, in Guatemala and Honduras, some of the previously estimated positive effects of remittances are now found to be larger in magnitude for children with uneducated mothers and considerably smaller for those whose mothers have at least four years of schooling.

Overall, with the addition of Paraguay and Peru to the list of countries where remittances affect educational attainment, we are left with only two countries (Jamaica and the Dominican Republic) in which those effects are always non-significant. As for the differences by gender and urban status, our estimation results do not allow easy generalizations and suggest that the various potential effects of migration and remittances - relaxation of budget constraints, social disruption, changes in the returns of schooling - carry different relative weights depending on the country and socio-economic group involved. In any case, it appears that remittances tend to relax budget constraints that otherwise would have forced children to leave school and reduce their educational attainment, but this effect is sometimes restricted to those with less educated mothers.

\section{IV.2. Health Outcomes}

Few papers have addressed the impact of migration and remittances on child health, and the exceptions are mostly focused on infant mortality. For instance, Brockerhoff (1990) and Ssengonzi, De Jong and Stokes (2002) investigate the effects of female migration on the survival chances of their children in Senegal and Uganda, respectively. They find that rural to urban migration significantly increases child survival chances. Kanaiaupuni and Donato (1999) analyze the effects of village migration and remittances on infant survival outcomes in Mexico, and conclude that remittances reduce infant mortality. However, the authors reach an opposite conclusion for the effect of migration: higher rates of infant mortality in communities experiencing intense migration. Finally, with data on Mexican municipalities Lopez-Cordova (2005) concludes that larger proportions of remittances and migrant households at the community level are associated with lower infant mortality rates.

Further evidence on the impact of migration on other child health outcomes has been provided by Hildebrandt and McKenzie (2006) for the Mexican case. Their results show that migrant households have lower rates of infant mortality and higher birth weights. Moreover, they find evidence that migration also raises maternal health knowledge and the likelihood that the child was delivered by a doctor. On the other hand, preventative health care (breastfeeding, visits to doctors, and vaccinations) seem to be less likely for children from migrant households.

\footnotetext{
${ }^{9}$ In the case of Peru, the sample includes both urban and rural children together in order to achieve sufficient variation.
} 
However, no previous study has investigated the impact of remittances and migration on anthropometric indicators for young children (weight-for-age, height-for age), which are considered to be important measures of the health dimension of human capital accumulation and are extensively cited in the literature of health economics. For instance, Hoddinot and Kinsey (2001) present results on how external shocks drastically affect child growth in developing countries. It is a consensus in medicine that both weight and height measures are good indicators of health status, with different consequences in the short and long run. For instance, lower weight is usually associated with malnutrition and higher mortality risk. Similarly, lower stature in childhood is strongly correlated with lower body size in adulthood, with negative consequences on earnings and productivity (Thomas and Strauss, 1997), and increased risk of cardiovascular and lung diseases.

With this motivation, this section assesses the effect of international migrant remittances on anthropometric health indicators typically used in the health literature, and with well known links with child growth. We also estimate the impact of remittances on others health measures as those addressed in Hildebrandt and McKenzie (2006), such as the probability that the delivery of children born in the year preceding the survey was assisted by a doctor, and on the probability that children aged 2 to 5 received the complete set of required vaccinations. The anthropometric measures on which we focus are the Weight-for-Age (WAZ) and Height-for-Age (HAZ) ZScores for children aged 1 to 5 years old. These are standardized measures of performance in weight and height, and consist on comparing each child of a given age to a reference group. The reference tables for WAZ and HAZ are taken from the CDC Growth Charts for US (Kuczmarski et al., 2000). ${ }^{10}$ In particular, the following formula is used for calculating the Z-Scores:

$$
\mathrm{Z}=\frac{\left[\left(\frac{\mathrm{X}}{\mathrm{M}}\right)^{\mathrm{L}}-1\right]}{L S}
$$

where $X$ is the measure of interest (weight, height) for the child, $M$ is the median of the corresponding variable, $S$ is the generalized coefficient of variation, and $L$ is the power in the Box-Cox transformation taken from the CDC reference tables for a given age group. In order to avoid extreme values and outliers due to misreporting, we follow Hoddinott and Kinsey's (2001) recommendation to drop children with z-scores greater than 6 or lower than -6 . As the original reference tables account for children with 1.5, 2.5, 3.5, etc. months, in order to match our data the reference months are rounded up (i.e., 1.5 month in the reference table are equal to 2 months). ${ }^{11}$

Figures 6 and 7 show the distribution of weight-for-age and height-for-age anthropometric z-scores for the cases of Guatemala and Nicaragua, the only two LAC countries for which the available household surveys provide the information needed for calculating the

\footnotetext{
${ }^{10}$ Reference Tables can be found at www.cdc.gov/nchs/about/major/nhanes/growthcharts/datafiles.htm

${ }^{11}$ For WAZ, the original tables used are the "Weight-for-age charts, birth to 36 months", for children from 0 up to 36 months. For older children, values where extrapolated using the "Weight-for-age charts, 2 to 20 years". Similarly, for HAZ the reference tables used are "Length-for-age charts, birth to 36 months", for children from 0 up to 36 months, and "Stature-for-age charts, 2 to 20 years", for older children.
} 
health indicators employed in this section (weight and height of young children). Plot densities of the above described anthropometric indicators for children aged 1-5 years old from remittance recipient and non-recipient households are estimated using kernel densities. The figures show that children from recipient households have both higher weight-for-age and height-for age zscores. Kolmogorov-Smirnov tests reject the equality of distributions for recipient and nonrecipient households, and suggest that remittances are in fact associated with better children anthropometric scores.

\section{Figure 6. Anthropometric Measures for Children aged 1 to 5, by Remittance Recipient Status - Guatemala.}
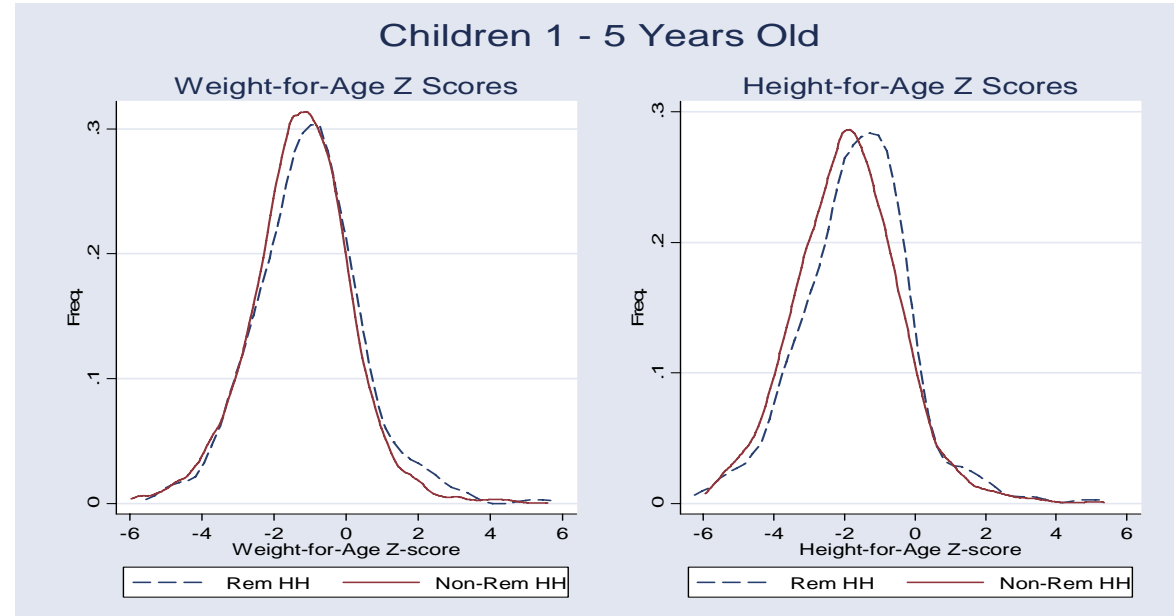

Source: Author's calculations based on household surveys

\section{Figure 7. Anthropometric Measures for Children aged 1 to 5, by Remittance Recipient Status - Nicaragua.}

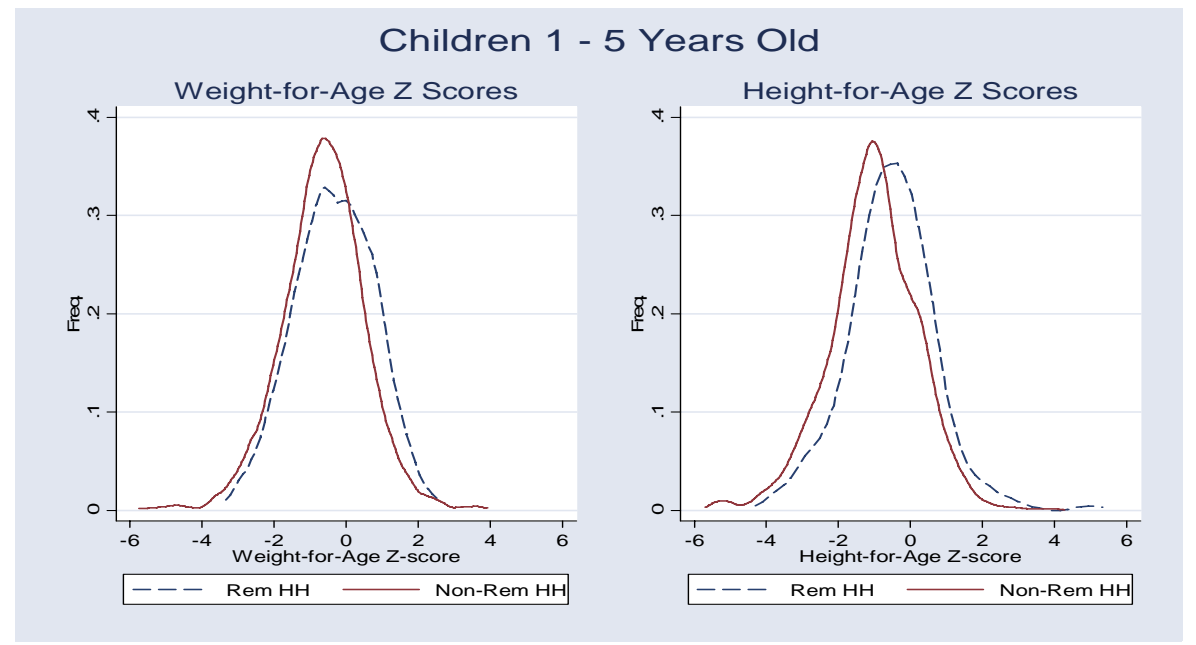

Source: Author's calculations based on household surveys

In order to test whether these results are driven by the differential characteristics of households with and without migrants, we estimate a regression model similar to the one used for educational attainment (equation 4), changing only the dependent variable, from years of 
schooling to the four health indicators measured above. In addition to this basic specification, we estimate a modified version of equation (4), where the indicator for remittances recipients is interacted with a dummy variable for the second quintile of the income distribution - using the counterfactual income prior to migration - and a dummy for households located in the third to fifth quintiles. $^{12}$

Table 10 reports the corresponding results, including the coefficients on free-standing dummy variables for the second through fifth income quintiles. As confirmed by our estimates, both weight- and height-for-age indexes tend to increase monotonically and significantly with household income, and so does the likelihood of doctor-assisted deliveries in the case of Nicaragua. Moreover, controlling for pre-migration income, children from households that report receiving remittances tend to exhibit higher health outcomes than those from non-recipients households with similar demographic and socio-economic characteristics. While the relatively small sample sizes make most of the estimated interactives between remittances and income quintiles non-significant from a statistical point of view, in most cases the results clearly indicate that the impact of remittances on children health is concentrated on low-income households located in the first quintile of the income distribution.

Table 10. Remittances and Health Outcomes

\begin{tabular}{|l|cc|c|c|cc|c|c|}
\hline Country & \multicolumn{4}{|c|}{ Guatemala } & \multicolumn{4}{c|}{ Nicaragua } \\
\hline \multirow{2}{*}{ Dependent Variable } & $\begin{array}{c}\text { Weight-for- } \\
\text { Age Z-Score }\end{array}$ & $\begin{array}{c}\text { Height-for- } \\
\text { Age Z-Score }\end{array}$ & $\begin{array}{c}\text { Received All } \\
\text { Vaccines }\end{array}$ & $\begin{array}{c}\text { Child } \\
\text { Delivered by } \\
\text { Doctor }\end{array}$ & $\begin{array}{c}\text { Weight-for- } \\
\text { Age Z-Score }\end{array}$ & $\begin{array}{c}\text { Height-for- } \\
\text { Age Z-Score }\end{array}$ & $\begin{array}{c}\text { Received All } \\
\text { Vaccines }\end{array}$ & $\begin{array}{c}\text { Child } \\
\text { Delivered by } \\
\text { Doctor }\end{array}$ \\
\hline \multirow{3}{*}{ 2nd Income Quintile } & $0.117^{* *}$ & $0.141^{* *}$ & 0.011 & 0.006 & $0.154^{*}$ & $0.230^{* *}$ & -0.028 & $0.104^{*}$ \\
& $(0.058)$ & $(0.060)$ & $(0.011)$ & $(0.015)$ & $(0.085)$ & $(0.091)$ & $(0.047)$ & $(0.060)$ \\
3rd Income Quintile & $0.233^{* * *}$ & $0.385^{* *}$ & 0.016 & $0.054^{* * *}$ & 0.077 & $0.327^{* * *}$ & -0.011 & 0.085 \\
& $(0.060)$ & $(0.067)$ & $(0.013)$ & $(0.025)$ & $(0.099)$ & $(0.109)$ & $(0.054)$ & $(0.070)$ \\
4th Income Quintile & $0.325^{* * *}$ & $0.479^{* *}$ & 0.010 & 0.023 & $0.263^{* *}$ & $0.594^{* * *}$ & -0.126 & $0.168^{*}$ \\
& $(0.073)$ & $(0.076)$ & $(0.016)$ & $(0.023)$ & $(0.117)$ & $(0.113)$ & $(0.062)$ & $(0.079)$ \\
5th Income Quintile & $0.594^{* * *}$ & $0.686^{* *}$ & 0.026 & 0.013 & $0.352^{* *}$ & $0.594^{* * *}$ & -0.102 & $0.263^{* *}$ \\
& $(0.091)$ & $(0.098)$ & $(0.018)$ & $(0.025)$ & $(0.138)$ & $(0.136)$ & $(0.078)$ & $(0.082)$ \\
\hline Remittances & $0.211^{* *}$ & 0.213 & $0.065^{* *}$ & $0.255^{* * *}$ & 0.306 & 0.289 & 0.119 & $0.297 * *$ \\
& $(0.089)$ & $(0.228)$ & $(0.021)$ & $(0.160)$ & $(0.394)$ & $(0.347)$ & $(0.225)$ & $(0.090)$ \\
\hline Remittances*Q2 & -0.327 & 0.084 & -0.082 & $-0.034^{*}$ & -0.370 & -0.079 & 0.034 & $-0.463^{*}$ \\
Remittances*Q3-Q4-Q55 & $(0.283)$ & $(0.264)$ & $(0.079)$ & $(0.007)$ & $(0.457)$ & $(0.421)$ & $(0.275)$ & $(0.225)$ \\
& -0.423 & 0.004 & -0.041 & $-0.036^{* * *}$ & -0.252 & -0.148 & 0.071 & $-0.623^{* * *}$ \\
& $(0.272)$ & $(0.253)$ & $(0.071)$ & $(0.006)$ & $(0.418)$ & $(0.385)$ & $(0.252)$ & $(0.114)$ \\
& & & & & & & & \\
\hline
\end{tabular}

Notes: *** Significant at $1 \%$ level. ${ }^{* *}$ Significant at $5 \%$ level. * Significant at $10 \%$ level.

Regressions include the same set of controls as in Table 5. Source: Author's calculations based on household surveys.

\section{Conclusions}

This paper has explored the development impact of remittances in eleven Latin American countries. If we were to summarize the results of the paper into a few main messages they would be the following: (i) In general remittances appear to lower poverty levels in recipient countries.

\footnotetext{
${ }^{12}$ We group the $3^{\text {rd }}$ through $5^{\text {th }}$ quintiles due to the relatively small sample size for some of the estimations.
} 
This result is robust to the use of counterfactual scenarios that input the potential input that the migrant may have had at home. (ii) Yet, despite this general tendency the estimated impact of remittances on poverty tends to be modest in all the experiments performed. Clearly, when the counterfactual scenario is one of no migration the result is even more modest than when the counterfactual is one of no remittances. (iii) There is significant country heterogeneity in the obtained results. Among the aspects that have been identified in the paper that may lead to a particular outcome in a given country, one could mention: the percentage of households receiving remittances; the share of those with remittances belonging to the lowest quintiles of the income distribution; and the dollar amount of remittances with respect to GDP. (iv) While there is evidence that for some specific groups - defined by country, gender, and urban status remittances increase children's educational attainment, the impact is often restricted to children with low levels of parental schooling. Thus, once again there is a need to qualify the positive development impact of remittances. In the case of health outcomes the results are restricted to two countries - Nicaragua and Guatemala - but in both cases they suggest that remittances improve children's health, particularly among low-income households. 


\section{References}

Acosta, P. (2006): "Labor Supply, School Attendance, and Remittances from International Migration: The Case of El Salvador” World Bank Policy Research Working Paper 3903, The World Bank, Washington, DC.

Acosta, P., C. Calderon, P. Fajnzylber, and H. Lopez (2006): "Remittances and Development in Latin America”, World Economy 29: 957-987.

Acosta, P., C. Calderon, P. Fajnzylber, and H. Lopez (2007): "What is the Impact of International Remittances on Poverty and Inequality in Latin America?”, World Development, forthcoming.

Adams, R. (2004): "Remittances and Poverty in Guatemala." World Bank Policy Research Working Paper 3418, The World Bank, Washington, DC.

Adams, R. (2006): “Remittances and Poverty in Ghana.” World Bank Policy Research Working Paper 3838, The World Bank, Washington, DC.

Adams, R., and J. Page (2005): "Do International Migration and Remittances Reduce Poverty in Developing Countries?”, World Development 33: 1645-1669.

Amuedo-Dorantes, C. and S. Pozo (2004): "Workers' Remittances and the Real Exchange Rate: A Paradox of Gifts”, World Development 32: 1407-1417.

Barham, B., and S. Boucher (1998): "Migration, Remittances, and Inequality: Estimating the Net Effects of Migration on Income Distribution”, Journal of Development Economics 55: 307-331.

Brockerhoff, M. (1990): "Rural-to-Urban Migration and Child Survival in Senegal", Demography, 27, 601-616.

Cox-Edwards, A., and M. Ureta (2003): “International Migration, Remittances, and Schooling: Evidence from El Salvador”, Journal of Development Economics 72: 429-461.

Deaton, A. (2005): "Measuring Poverty in a Growing World (or Measuring Growth in a Poor World)" The Review of Economics and Statistics 87(1): 1-19.

Hanson, G. H., and C. Woodruff (2003): "Emigration and Educational Attainment in Mexico" mimeo, University of California, San Diego, California.

Heckman, J. J. (1979): “Sample selection bias as a specification error”, Econometrica , 47, 153161.

Hildebrandt, N., and D. McKenzie (2005): "The Effects of Migration on Child Health in Mexico”, Economia, Journal of the Latin American and Caribbean Economic Association 6, 257-289. 
Hoddinott, J., and B. Kinsey (2001): "Child Growth in the Time of Drought”, Oxford Bulletin of Economics and Statistics, 63, 409-436.

Kanaiaupuni, S., and K. Donato (1999): "Migradollars and Mortality: The Effects of Migration on Infant Survival in Mexico”, Demography 36: 339-353.

Kuczmarski, R., C. Ogden, L. Grummer-Strawn, K. Flegal, S. Guo, R. Wei, Z. Mei, L. Curtin, A. Roche, and C. Johnson (2000): “CDC Growth Charts: United States”. Advance Data from Vital and Health Statistics, 314. Hyattsville, MD: National Center for Health Statistics.

Lopez Cordova, E. (2005): “Globalization, Migration and Development: The Role of Mexican Migrant Remittances” Economia, Journal of the Latin American and Caribbean Economic Association 6, 217-256.

McKenzie, D., and H. Rapoport (2006): "Can migration reduce educational attainment ? Evidence from Mexico", World Bank Policy Research Working Paper 3952, The World Bank, Washington, DC.

Rajan, R., and A. Subramanian (2005): “What Undermines Aid’s Impact on Growth?”, mimeo, International Monetary Fund, Washington, DC.

Rodriguez, E. R. (1998): “International Migration and Income Distribution in the Philippines”, Economic Development and Cultural Change, 46(2), 329-50.

Rodriguez, E. and E. Tiongson (2001): “Temporary Migration Overseas and Household Labor Supply: Evidence from Urban Philippines”, International Migration Review, 35, 1185-204.

Ruiz-Arranz, M., and P. Giuliano (2005): “Remittances, Financial Development, and Growth”. IMF Working Paper No. 05/234, Washington, DC.

Schiff, M. (2006): “Migration's Income and Poverty Impact Has Been Underestimated”, IZA Discussion Paper No. 2088.

Ssengonzi, R., G. De Jong, and C. Stokes (2002): “The Effect of Female Migration on Infant and Child Survival in Uganda”, Population Research and Policy Review, 21, 403-431.

Taylor, J. E., J. Mora, R. Adams, and A. Lopez-Feldman (2005): “Remittances, Inequality, and Poverty: Evidence from Rural Mexico”, mimeo, University of California.

Thomas, D., and J. Strauss (1997): "Health and wages: Evidence on men and women in urban Brazil", Journal of Econometrics 77, 159-185.

Woodruf, C. and R. Zenteno (2007): "Migration Networks and Microenterprises in Mexico", Journal of Development Economics 82, 509-528. 
Yang, D. (2006): “Coping with Disaster: The Impact of Hurricanes on International Financial Flows, 1970-2001”, mimeo, University of Michigan, Ann-Arbor.

Yang, D., and C. Martinez (2006): “Remittances and Poverty in Migrants' Home Areas: Evidence from the Philippines”. In C. Ozden, M. Schiff (Eds.), International Migration, Remittances and the Brain Drain (pp. 81-121). Washington, DC: The World Bank. 